Review

\title{
Nutritional management and prevention of oral mucositis in haematology and oncology cancer patients undergoing antineoplastic treatments
}

\author{
Balma García-Gozalbo ${ }^{1}$ and Luis Cabañas-Alite ${ }^{1^{*}}$
}

1 Universitat de València, Valencia

* Correspondence: hola@comocuandocomo.com

\begin{abstract}
Cancer is a prevalent disease worldwide and treatments such as radiotherapy and chemotherapy sometimes lead to adverse events. Oral mucositis is one of the most disabling and clinical guidelines do not take into account nutritional interventions. The primary endpoint was to gather the evidence about the efficacy of nutritional interventions in the prevention and/or treatment of antineoplastic induced oral mucositis in oncological patients. It was carried out a bibliographic review in PubMed data base by combining MesH terms with boolean operators. Articles were selected based on inclusion and exclusion criteria; 50 final articles were found. Although further evidence is needed, glutamine, honey and vitamins appear to be a good therapeutic option. The rest of the compounds presented controversial or insufficient results to draw conclusions over their utilization as prevention or treatment options. Low evidence is reported about oral mucositis nutritional interventions in spite of being attainable and affordable compounds. Scarce evidence is shown in paediatric patients compared to adults. Developing higher quality studies and combinations with the compounds researched is necessary to create stronger evidence.
\end{abstract}

Keywords: cancer; oral mucositis; diet therapy

\section{Introduction}

The World Health Organization (WHO) conceptualizes cancer as a generic term which includes a wide group of diseases that can affect any part of the organism. They are also called "malignant tumours" or "malignant neoplasms". A defining characteristic of cancer is the rapid division of abnormal cells that extend beyond the common limits and can invade adjacent parts of the body or spread to other organs, a process called metastasis. Metastasis is the main cause of death due to cancer disease [1]. It is indispensable to highlight the word "group" of diseases, considering that they are different entities with common characteristics such as their genetical origin, uncontrolled proliferation, resistance to cell death and capability to invade adjunctive tissues or metastasize in distant organs [2]. Based on this definition, we can indicate the global situation on morbidity and mortality on account of cancer. From the data reported by the international agency for cancer research (IARC) in 2018, we can elucidate that the incidence went up to 18.1 million cases and the mortality scaled to 9.6 million. Also, lung, colorectal and mammary cancers are still the most incident of all. Furthermore, women death rates are lower than men rates [3]. When neoplastic processes are diagnosed, they come alongside a treatment. Whether chemotherapy or radiotherapy is used, adverse events are found, being oral mucositis one of the most common among others such as diarrhoea or vomiting [4]. It is estimated that conditioning regimens for stem cell transplantation are the ones that generate the highest rates of oral mucositis incidence, followed by radiotherapy and lastly by chemotherapy [5-9]. 
All things considered; it is possible now to define oral mucositis more specifically, which is defined as the inflammation of oral mucosa with clinical consequences such as ulcers or erythema secondary to radiotherapeutic or chemotherapeutic treatments [10]. This term differs from the unit "mucositis", which is considered the damage and inflammation of oral, pharyngeal, laryngeal and oesophagal mucosa, together with other areas of the gastrointestinal tract secondary to antineoplastic treatments such as radiotherapy and chemotherapy [8]. Likewise, sometimes the word "stomatitis" is used as a synonym for oral mucositis (OM) even though it is a different entity, because it defines the inflammation in the oral mucosa due to other specific aetiology unrelated to antineoplastic treatments (e.g. infections) [10,11].

Multiple scales are used to assess OM, but none of them is agreed as a standardized scale. The classification divides them into general scales (e.g. WHO scale), scales with multiple variables (e.g. Beck, Eliers and Walsh scales) and the ones specific for the treatment (e.g. Oral Mucositis Rating, National Cancer Institute and Radiation Therapy Oncology Group/European Organization for Research and Treatment of Cancer scales) [12-14].

After OM is evaluated, it is possible to find either mild erythema and burnt mouth sensation or profound mouth ulcers and the inability to eat. Independently of the clinical presentation, its cause relies on a matrix of heterogeneous processes. Not only one physiopathological mechanism is the direct cause for OM but many complex biological routes. OM is typically based on five stages. The first two of them have an immediate appearance after chemotherapy, radiotherapy or chemoradiotherapy. The first phase is the so-called "initiation" and it is based on the death of basal epithelial cells (as a consequence of the treatment damage to the DNA in cells) along with the secretion of reactive oxygen species (ROS) and endogenous damage-associated pattern molecules (CRAMPs). The last of which, binds to specific receptors and set in motion the second stage. This second step is designated such as "primary damage response" and involves a cascade of biological events which interact with one another and conclude activating various transcription factors (nuclear factor Kappa-B (NF- $\kappa \mathrm{B})$, Wnt, p53, and their associated canonical pathways). For example, NF- $\kappa B$ route activation can be done directly (by the antineoplastic treatments) or indirectly (because of ROS and CRAMPs), evidencing the complexity of OM physiopathology. The activation of transcription factors produces the expression of a large number of genes, being some of them related to the production of molecules (eg, COX-2, inducible NO-synthase, superoxide dismutase...) which take part in the secondary emergence of OM. Other routes directly linked with the onset of this pathology exist, such as the nitrogen metabolism pathway, ceramide and fibrinolysis route, and the stimulation of matrix metalloproteinases (MMPs).

The third stage is called "signal amplification" and occurs when the primary response molecules have positive or negative feedback on the local tissue. Throughout this period there is no visible injury even though the submucous tissues and basal membrane are already damaged. Four to five days after the antineoplastic treatment, the destructive processes of the three first stages triggers before the fourth or "ulceration stage" begins. This phase implies the ulceration of the oral mucosa (transecting the full epithelial thickness), being the patients more prone to infections when this happens. Moreover, ulcers are colonized by oral bacteria worsening and making the initial injury last longer due to infiltrating macrophages generating pro-inflammatory cytokines. The "healing stage" or last phase consists of the remission of the oral cavity injuries spontaneously. This event happens as a result of the activation from signaling molecules (extracellular matrix) which direct the migration, proliferation, and differentiation of the epithelium bordering ulcerative areas [11].

Managing $\mathrm{OM}$ is complex. Clinical practice guidelines (CPG) on this topic are scarce and not recent in its vast majority, with exceptions. The Multinational Association of Supportive Care in Cancer and International Society of Oral Oncology (MASCC/ISOO) 
has the most recent clinical practice guideline on oral mucositis prevention and treatment topic.

Strategies such as basic oral care are beneficial practices with a low grade of evidence. Therefore, procedures such as a multiagent combination of oral care protocols (a guide about the time, frequency and products that patients with cancer should use every day) are considered beneficial to prevent OM from appearing and others like chlorhexidine rinses are contraindicated to prevent it (grade III evidence), nevertheless saline or bicarbonate sodium rinses, patient education and professional oral care have insufficient evidence to determine whether they positively or negatively impact OM. It is recommended to use benzydaminerinses to prevent OM in patients with head and neck cancers undergoing radiotherapy (RT) or chemotherapy (CT) (grade I and II evidence respectively). Other anti-inflammatory drugs were studied and none of them had enough evidence to present a recommendation $[8,15,16]$.

Regarding other drugs, sucralfate is not recommended as prevention or treatment, whereas topical morphine $(0,2 \%)$ is suggested for OM treatment when it is associated with pain (low evidence grade III) in patients with head and neck cancer undergoing CT and RT. Oral cryotherapy (ice therapy), in contrast, is recommended to prevent OM onset thirty minutes before receiving 5-fluorouracil (5-FU) boluses meanwhile CT, or whether a patient is treated with melphalan in high doses previous to an autologous stem cell transplantation (which means that the donor and receptor are the same human)[8,15,16].

The use of intravenous keratin growth factor (KGF-1) is recommended for the prevention of $\mathrm{OM}$ in patients affected by haematologic cancer before an autologous stem cell transplantation with conditioning regimens including high dose CT and total body irradiation (TBI). In this context, neither topical granulocyte-macrophage colony-stimulating factor (GM-CSF) nor parenteral glutamine should be used in the prevention of OM in stem cell transplantation in contrast to what has been said about KFG-1. However, experts suggest using oral glutamine to prevent OM from appearing in patients with head and neck cancer undergoing CT and RT (grade II evidence). Finally, it is considered to use honey to prevent OM in patients with head and neck cancer who are treated with RT or CT and RT [15-16].

The existing clinical practice guidelines about OM don't or poorly address nutritional approach treatment, leaving unresolved doubts and evidence voids on which interventions should be done. This study pretends to address which nutrients can be administered to prevent and/or treat CT and RT induced OM in cancer patients.

\section{Materials and Methods}

Literature Research

Main aim: To establish the effect of nutritional interventions on the prevention or treatment of oral mucositis in cancer patients undergoing radiotherapy and/or chemotherapy. This paper is based on a bibliographic review of the published information from 2000 to 2021. The literature chosen to be reviewed dates back from October 2020 to April 2021, which includes the latest results of the research strategy used (see supplementary material).

The bibliographic research was carried out at PubMed and Medline database, finding 252 results.

\section{Study Eligibility, selection and Data Extraction.}

On one hand, research articles were selected taking into account the following inclusion criteria: 1) original articles, 2) articles published between 2000 and 2021, and 3) those written in English and Spanish. On the other hand, exclusion criteria were: 1) reviews with or without meta-analysis, 2) topics of the article unrelated to the research subject matter, 3) articles whose aim was treating animals as a veterinary care strategy, and 4) qualitative research articles.

The screening process can be observed in Figure 1. 


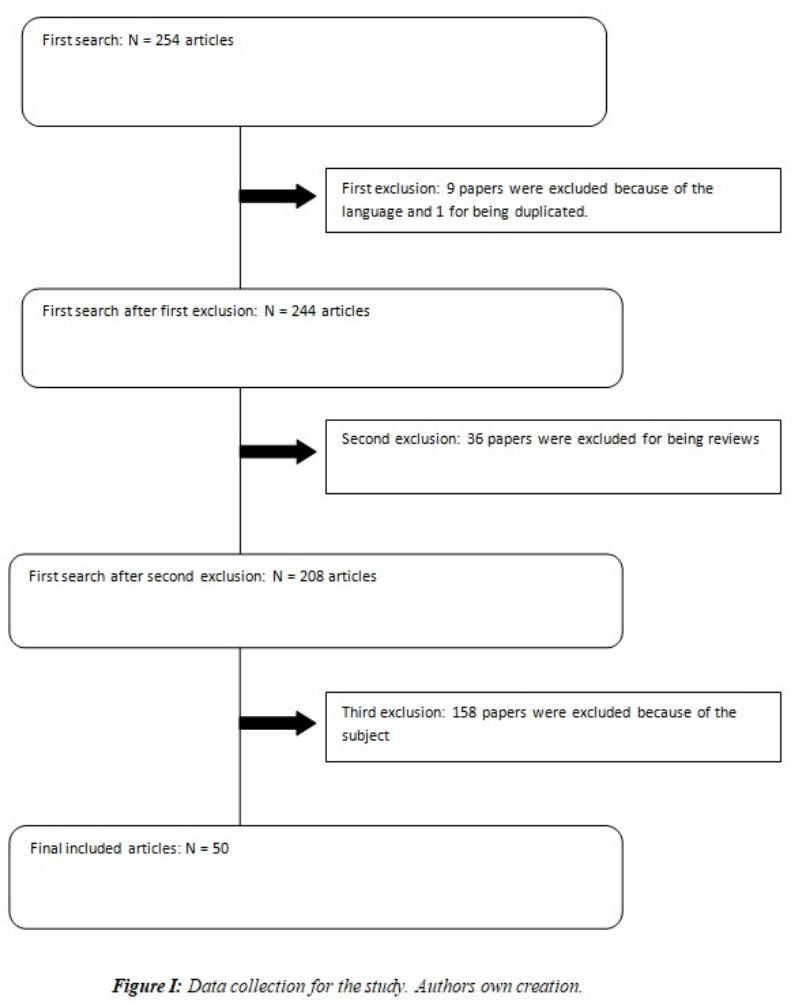

The review process was completed by two reviewers independently and blindfolded, in other words, without knowing the other reviewer decisions, the scientific journal, the reference or the author.

As shown in Figure I, 46 articles were excluded after the first screening process made by reading the title and abstract of each article. Out of these 46 articles, 9 of them were excluded due to their language, 1 because of duplication, and 36 for being reviews. In this article, 208 references were selected beforehand to be submitted to a second screening process which consisted of a full reading and an analysis of its relevance to be included in the review. Those references that were not considered useful for this study were excluded (158).

\section{Results}

Following the literature research, 254 articles were identified. After excluding 204 of them, 50 articles that met the inclusion criteria remained and were included in the final review. Figure 1 further outlines the selection process used. A narrative analysis of the studies revealed two types of population (paediatric and adults), and three key themes emerged: Glutamine, Honey and Other Dietary Components or Prevention Methods. The results are classified according to these themes. Articles included in the final review can also be seen in Table 1.

\subsection{Summary of the Studies Included}

Paedriatic population

Of the final articles included, six of them approached the prevention and/or treatment of $\mathrm{OM}$ in paediatric patients with cancer. Ages evaluated in those articles went from one to nineteen years old, varying in the different scientific articles. Also, all the articles majorly approached haematological neoplasms, even though some included solid tumours in their sample (in lessening proportion). Four of the studies were based on 
clinical trials, whereas the other two were based on a cohort study and a case series study. The four trials studied different compounds.

\section{Glutamine}

From the reviewed articles, 18 articles retrieved were related to different preparations of glutamine for the prevention and treatment of OM in adults with cancer. All the studies were performed in population that ranged from 19 to 70 years old. The most frequent ages groups were those ranging 30 and 50 years old. The overall articles consisted of 15 clinical trials, 1 cohort study and 2 laboratory studies (one in vivo and the other in vitro and in vivo).

Regarding clinical trials, it can be stated that their nature is heterogeneous. More specifically due to the fact that different levels of methodological blindness exist (double and triple blindness, open trials, preliminary, etc.), and there are differences in the treated disease, the used therapy (CT, RT or CRT), even OM grading scale.

\section{Honey}

Another compound studied as a possible prevention and/or treatment for OM is honey. Having retrieved after a preliminary research, 8 articles about it. Out of these, 7 articles were designed as a research with different types of blinded clinical trials and 1 of them was a laboratory study (in vitro and in vivo).

Other Dietary Components or Prevention Methods found).

Vitamins were another group that was analysed in different studies, (7 articles

Liquorice was studied in 3 clinical trials, establishing different results.

Cryotherapy was examined in 2 articles in which was determined a reduction of OM incidence and severity.

It must be highlighted that there are also two compounds analysed (date palm pollen and polideoxyribonucleotides) in the present study which weren't possible to compare with the existent scientific literature since they have only been researched in 1 article. However, their results were positive, being in need of further evidence to provide new approaches to the prevention and treatment of OM induced by antineoplastic therapies. 


\begin{tabular}{|c|c|c|c|c|c|c|}
\hline Author (year) & $\mathrm{N}$ & $\begin{array}{l}\text { Study } \\
\text { desing }\end{array}$ & Objetive & Intervention & Time (months) & Conclusion \\
\hline $\begin{array}{l}\text { Huang et al. } \\
\qquad(2019)\end{array}$ & 59 & $\begin{array}{c}\text { RCT } \\
\text { Phase III, } \\
\text { double-bli } \\
\text { nd }\end{array}$ & $\begin{array}{l}\text { To evaluate if oral glutamine } \\
\text { prevents acute toxicities (OM and } \\
\text { dermatitis) secondary to the } \\
\text { treatment with RT in patients with } \\
\text { head and neck cancers. }\end{array}$ & $\begin{array}{l}\text { - } \text { Glutamine (TG). } \\
\text { - Control: maltodextrin } \\
\text { (CG) } \\
\text { NCI CTCAE } 4.03 \text { version }\end{array}$ & 19 & $\begin{array}{l}\text { CG developed more OM (grades 2-4) than TG; nevertheless, the } \\
\text { efficacy of the treatment with oral glutamine is not meaningfu } \\
\text { after RT in head and neck cancers. }\end{array}$ \\
\hline $\begin{array}{l}\text { Tsujimoto et al. } \\
\qquad \text { (2015) }\end{array}$ & 40 & $\begin{array}{l}\text { RCT, } \\
\text { double-bli } \\
\text { nd }\end{array}$ & $\begin{array}{l}\text { To evaluate if oral glutamine } \\
\text { reduces mucositis severity induced } \\
\text { by CRT in patients with head and } \\
\text { neck cancer. }\end{array}$ & $\begin{array}{l}\text { - } \quad \text { Glutamine (TG). } \\
\text { - } \quad \text { Placebo (PG). } \\
\text { NCI CTCAE } 3.0 \text { version }\end{array}$ & 36 & $\begin{array}{l}\text { Oral glutamine reduced } \mathrm{OM} \text { severity produced by } \mathrm{CT} \text { in head } \\
\text { and neck cancer patients with a maximum mean grade of } \mathrm{OM} \\
\text { lower for TG than to } \mathrm{PG} \text {, a duration without meaninfgu } \\
\text { difference between both groups and a less duration of artificia } \\
\text { nutrition required in TG. }\end{array}$ \\
\hline $\begin{array}{c}\text { Tanaka et al. } \\
\text { (2016) }\end{array}$ & 30 & $\begin{array}{c}\text { RCT } \\
\text { Phase II }\end{array}$ & $\begin{array}{l}\text { To assess if glutamine and the } \\
\text { combination of glutamine and } \\
\text { elemental diet reduce the incidence } \\
\text { of } \mathrm{CT} \text { induced } \mathrm{OM} \text { in patients with } \\
\text { oesophagal cancers. }\end{array}$ & $\begin{array}{ll}\text { - } & \text { Placebo (PG) } \\
\text { - } & \text { Glutamine (TG) } \\
\text { - } & \text { Glutamine + elemental } \\
& \text { diet (CTG). } \\
\text { NCI CTCAE } 3.0 \text { version }\end{array}$ & 36 & Without differences between PG and TG \\
\hline $\begin{array}{l}\text { Pachón et al. } \\
\text { (2018) }\end{array}$ & 262 & $\begin{array}{l}\text { Prospectiv } \\
\text { e cohort } \\
\text { study }\end{array}$ & $\begin{array}{l}\text { To evaluate if oral glutamine } \\
\text { prevents mucositis induced by } \\
\text { oncological therapies (CRT or RT) in } \\
\text { patients with head and neck cancer. }\end{array}$ & $\begin{array}{l}\text { - } \quad \text { Oral glutamine (TG). } \\
\text { - } \quad \text { Placebo (PG). } \\
\text { RTOG/EORTC (MO } \\
\text { andoesophagitits) }\end{array}$ & - & $\begin{array}{l}\text { More OM in PG (RR:1,78), without remarcable differences in } \\
\text { severity. Higher odinophagia in PG (RR:2,87), with more } \\
\text { severity ( } R=4,33 \text { ).In PG more discontinuity in the treatment. }\end{array}$ \\
\hline $\begin{array}{c}\text { Chang et al. } \\
\text { (2019) }\end{array}$ & 60 & $\begin{array}{c}\text { RCT } \\
\text { Triple-blin } \\
\text { d }\end{array}$ & $\begin{array}{l}\text { To measure the impact of oral } \\
\text { glutamine as a supplement on the } \\
\text { prevention of oesophagitis induced } \\
\text { by CRT in patients with advanced } \\
\text { non-small cell lung cancer (stages } \\
\text { III-IV). }\end{array}$ & $\begin{array}{l}\text { - Placebo (PG) } \\
\text { - Oral glutamine (TG). } \\
\text { ARIE: acute radiation } \\
\text { induced oesophagitis }\end{array}$ & 12 & $\begin{array}{l}\text { TG had less severe ARIE than PG. Also a reduction of the } \\
\text { incidence in the weight loss in TG. }\end{array}$ \\
\hline $\begin{array}{c}\text { Anturlikaret al. } \\
\text { (2019) }\end{array}$ & 20 & $\begin{array}{l}\text { In vitro } \\
\text { and in vivo } \\
\text { study }\end{array}$ & $\begin{array}{l}\text { To measure the security and efficacy } \\
\text { of "HTOR-091516" } \\
\text { (Tumeric, Triphala and honey) as a } \\
\text { treatment of OM induced by 5-FU }\end{array}$ & $\begin{array}{l}\text { IN VITRO: gingival human } \\
\text { fibroblast, } \quad \text { mouse } \\
\text { connective tissue and } \\
\text { human oral reconstructed }\end{array}$ & 0.5 (14 days) & $\begin{array}{l}\text { The average weight loss in TG was lower, there also was les } \\
\text { mortality and a reduction in OM grade (WHO scale). The } \\
\text { product is proposed to prevent OM. }\end{array}$ \\
\hline
\end{tabular}




\begin{tabular}{|c|c|c|c|c|c|c|}
\hline & & & (CT). & 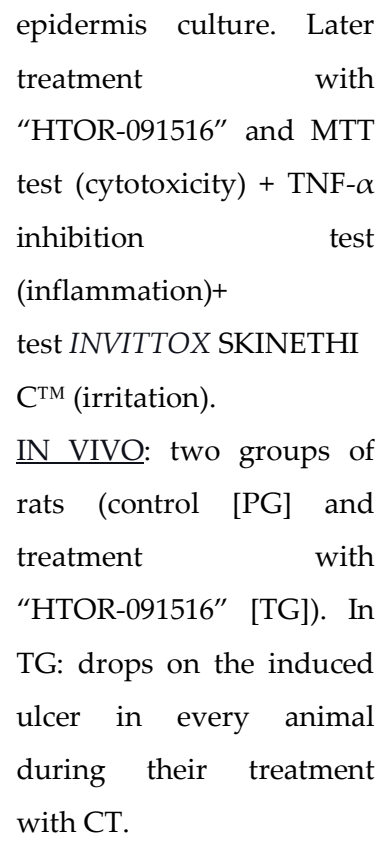 & & \\
\hline Cho et al. (2019) & 91 & CT & $\begin{array}{l}\text { To assess the effect of glutamine } \\
\text { enriched parenteral nutrition (PN) on } \\
\text { weight, infections, complications } \\
\text { (mucositis, neutropenia and graft } \\
\text { versus host disease) and mortality in } \\
\text { patients who undergone } \\
\text { hematopoietic stem cell } \\
\text { transplantation. }\end{array}$ & $\begin{array}{ll}\text { - } & \text { Control (CG). } \\
\text { - } & \text { Glutamine (TG) } \\
\text { through Dipeptiven® } \\
\text { (bottle). }\end{array}$ & 48 & $\begin{array}{l}\text { Without significative association in the case of OM duration. It } \\
\text { was noted a descent in 100-days mortality for TG. }\end{array}$ \\
\hline $\begin{array}{l}\text { Shumsky et al. } \\
\qquad(2019)\end{array}$ & 15 & Pilot RCT & $\begin{array}{l}\text { To evaluate the efficacy of Oncoxin } \\
\text { (ONCX) in oncologic patients with } \\
\text { OM who undergo CT, RT or both. }\end{array}$ & $\begin{array}{c}\text { - } \quad \text { Control group (CG). } \\
\text { - } \quad \text { Grupo ONCX (OG). } \\
\text { WHO Scale }\end{array}$ & 0.6 (20 days) & $\begin{array}{l}\text { The was found a lower OM grade in OG (after } 7 \text { days of } \\
\text { treatment and towards the end of their treatment) }\end{array}$ \\
\hline
\end{tabular}




\begin{tabular}{|c|c|c|c|c|c|c|}
\hline $\begin{array}{c}\text { Widjaja et al. } \\
\quad(2020)\end{array}$ & 48 & $\begin{array}{l}\text { Double-bli } \\
\text { nd RCT }\end{array}$ & $\begin{array}{l}\text { To measure if oral glutamine } \\
\text { prevents OM during CT (metotrexate } \\
{[\mathrm{MTX}] \text { in paediatric patients with }} \\
\text { acute lymphoblastic leukaemia } \\
\text { (ALL) }\end{array}$ & $\begin{array}{l}\text { - } \quad \text { Placebo group (PG). } \\
\text { - } \quad \text { Oral glutamine group } \\
\text { (TG) } \\
\quad \text { WHO Scale }\end{array}$ & 0.5 (14 days) & $\begin{array}{l}\text { There was a descent on the incidence and severity of OM in TG } \\
\text { after CT. }\end{array}$ \\
\hline $\begin{array}{l}\text { Harada et al. } \\
\text { (2018) }\end{array}$ & 50 & $\begin{array}{l}\text { In vitro } \\
\text { and in vivo } \\
\text { study }\end{array}$ & $\begin{array}{l}\text { To appraise the efficacy } \\
\text { of Elental@ (dietetic liquid } \\
\text { formulation enriched with amino } \\
\text { acids, which is a source of } \\
\text { L-glutamine) as 5-FU (CT) induced } \\
\text { OM and dermatitis treatment. }\end{array}$ & \begin{tabular}{ll}
\multicolumn{2}{l}{ IN VIVO: } \\
$-\quad$ Saline solution (PG). \\
- $\quad$ Dextrin group (DG). \\
- $\quad$ Elental group (EG).
\end{tabular} & 0.25 (8 days) & In vivo, $\mathrm{OM}$ healing faster than in $\mathrm{EG}$ \\
\hline $\begin{array}{l}\text { Oosterom et al. } \\
\text { (2019) }\end{array}$ & $\begin{array}{c}99(\mathrm{~A}) \mathrm{y} \\
81(\mathrm{~B})\end{array}$ & $\begin{array}{l}\text { Cohort } \\
\text { study }\end{array}$ & $\begin{array}{l}\text { A. To study the prevalence of } \\
\text { vitamin D deficiency in } \\
\text { paediatric patients } \\
\text { B. To establish a link between } \\
\text { vitamin D levels and } \\
\text { methotrexate (MTX) induced } \\
\text { OM in paediatric acute } \\
\text { lymphoblastic leukaemia (ALL). }\end{array}$ & $\begin{array}{l}\text { Vitamin D levels } \\
\text { before and after MTX } \\
\text { therapy. } \\
\text { After MTX, } \\
\text { classification in two } \\
\text { groups depending on } \\
\text { OM grade: } \geqslant 3 \text { or } \leqslant 3 \\
\text { NCI CTCAE 3.0 version }\end{array}$ & $2004-2012$ & $\begin{array}{l}\text { There was no association between basal vitamin D levels and } \\
\text { MTX induced OM, but low levels of vitamin D during MTX } \\
\text { therapy were found to be related to severe OM. }\end{array}$ \\
\hline Sun et al (2019) & 100 & $\begin{array}{l}\text { Double-bli } \\
\text { nd RCT }\end{array}$ & $\begin{array}{l}\text { To examine the effects of a group B } \\
\text { multivitamin complex combined } \\
\text { with GeneTime } \odot \text { (human } \\
\text { recombinant growth factor) on the } \\
\text { treatment of OM in patients with } \\
\text { head and neck cancer undergoing } \\
\text { RT. }\end{array}$ & $\begin{array}{l}\text { Control group with } \\
\text { vitamin B complex. } \\
\text { Observational group } \\
\text { with (OG) vitamin B } \\
\text { complex } \\
\text { GeneTime@. } \\
\text { RTOG scale. }\end{array}$ & 12 & $\begin{array}{l}\text { Less severity, affected area and healing time of the OM ulcers in } \\
\text { OG. }\end{array}$ \\
\hline
\end{tabular}




\begin{tabular}{|c|c|c|c|c|c|c|}
\hline $\begin{array}{c}\text { Nejatinamini et } \\
\text { al. (2018) }\end{array}$ & 28 & $\begin{array}{l}\text { Cohort } \\
\text { study }\end{array}$ & $\begin{array}{l}\text { To evaluate the changes in vitamin } \\
\text { status during the treatment of head } \\
\text { and neck cancers related to body } \\
\text { composition, inflammation and } \\
\text { mucositis. }\end{array}$ & $\begin{array}{ll}\text { - } & \text { Dietetic intake } \\
\text { measurement (3 days). } \\
\text { - } & \text { Vitamin levels } \\
\text { (vitamins D,E,B9 and } \\
\text { B12) } \\
\text { Basal (before } \\
\text { treatment) and } 6 \text { to } 8 \\
\text { weeks after RT } \\
\text { treatment (with or } \\
\text { without } \quad \text { CT) } \\
\text { C-reactive protein } \\
\text { (CRP) measurement. } \\
\text { C-reactive protein } \\
\text { (CRP) baseline before } \\
\text { and after } 6 \text { to } 8 \text { weeks } \\
\text { of RT treatment, either } \\
\text { with or without QT } \\
\text { after treatment. }\end{array}$ & $1-1,5$ & $\begin{array}{l}\text { Higher rates of OM were observed related to lesss vitamin D, } \\
\text { B12, E and B9 intake and lower blood levels of vitamin A and } \\
\text { D. }\end{array}$ \\
\hline $\begin{array}{c}\text { Tanaka et al. } \\
\text { (2018) }\end{array}$ & 19 & RCT & $\begin{array}{l}\text { To measure the intake of Elental }{ }^{\odot} \\
\text { during two cicles of CT and to } \\
\text { determine the incidence of OM in } \\
\text { patients with oesophagic cancers } \\
\text { treated with CT who completed their } \\
\text { intake and those who did not } \\
\text { completed it. }\end{array}$ & $\begin{array}{ll}\text { - } & \text { Elental }^{\odot} \text { group (CG). } \\
\text { - } & \text { Elental }^{\odot} \text { group with } \\
\text { uncompleted } \\
\text { treatment (UG). } \\
\text { CTCAE } 3.0 \text { version }\end{array}$ & 2 (56 days) & Less severity of OM in CG during CT with the use of Elental ${ }^{\circ}$. \\
\hline Pathak et al. & 56 & RCT & To assess the efficacy and role of oral & Control group (CG). & 1.75 (49 days) & TG had less hospitalizations due to $\mathrm{OM}$ and disphagia. \\
\hline
\end{tabular}




\begin{tabular}{|c|c|c|c|c|c|c|}
\hline (2019) & & & $\begin{array}{l}\text { glutamine in the treatment of OM } \\
\text { and disphagia induced by } \\
\text { chemoradiotherapy (CRT) in patients } \\
\text { with oropharynx and larynx } \\
\text { carcinoma. }\end{array}$ & $\begin{array}{l}\text { - Glutamine group } \\
\text { (TG). } \\
\text { NCI CTCAE } 4.03 \text { version }\end{array}$ & & More incidence and severity of OM in CG. \\
\hline $\begin{array}{l}\text { Mamgain et al. } \\
\text { (2020) }\end{array}$ & 127 & RCT & $\begin{array}{l}\text { To evaluate the efficacy of an } \\
\text { ayurvedic preparation (based on } \\
\text { Glycyrrhiza glabra) in order to } \\
\text { decrease the severity of mucositis in } \\
\text { patients with head and neck cancers } \\
\text { who receive chemoradiotherapy } \\
\text { (CRT). }\end{array}$ & $\begin{array}{l}\text { Comparison between basal } \\
\text { and post-RT } \\
\text { characteristics: } \\
\text { 1. Conventional OM } \\
\text { treatment (antiacids } \\
\text { and anaesthetics) } \\
\text { (CTG) } \\
\text { 2. Conventional and } \\
\text { treatment a a a a } \\
\text { ayurvedic preparation } \\
\text { (ATG). } \\
\text { 3. Honey and and } \\
\text { conventional } \\
\text { treatment (HTG). }\end{array}$ & 24 & $\begin{array}{l}\text { Less severity, pain and onset time of mucositis, both in ATG } \\
\text { and HTG, but especially in ATG. }\end{array}$ \\
\hline $\begin{array}{l}\text { Harada et al. } \\
\text { (2019) }\end{array}$ & 50 & Open RCT & $\begin{array}{l}\text { To evaluate changes in OM (injuries' } \\
\text { size, pain and redness + CRP in } \\
\text { plasma) in patients with oral } \\
\text { squamous cell carcinoma undergoing } \\
\text { CRT or RT with Elental }{ }^{\circ} \\
\text { administration. }\end{array}$ & $\begin{array}{l}\text { - } \quad \begin{array}{l}\text { Elental Group (EG). } \\
\text { - }\end{array} \text { Non-Elental Group as } \\
\text { the control (CG). } \\
\text { CTCAE } 4.0 \text { version }\end{array}$ & 24 & In EG, milder OM development in CRT; no difference in RT. \\
\hline Rao et al. (2017) & 49 & Blinded & To evaluate whether honey causes & Povidone-iodine & 6 & Lesser OM incidence and severity in HG. The implication on \\
\hline
\end{tabular}




\begin{tabular}{|c|c|c|c|c|c|c|}
\hline & & $\begin{array}{c}\text { single } \\
\text { centre RCT }\end{array}$ & $\begin{array}{l}\text { interferences with RT-induced } \\
\text { tumoral response or it exhibits a } \\
\text { positive effect against OM in patients } \\
\text { with head and neck cancer. }\end{array}$ & $\begin{array}{l}\text { group (CG). } \\
\text { - } \quad \text { Honey group (HG). } \\
\quad \text { RTOG scale. }\end{array}$ & & the treatment interruptions are not significant. \\
\hline $\begin{array}{l}\text { Branda et al. } \\
\qquad(2004)\end{array}$ & 68 & $\begin{array}{l}\text { Pilot } \\
\text { cohort } \\
\text { study }\end{array}$ & $\begin{array}{l}\text { To study the influence of } \mathbf{B 1 2} \\
\text { vitamin, folate and dietetic } \\
\text { supplements on CT-induced toxicity } \\
\text { in breast cancer patients. }\end{array}$ & 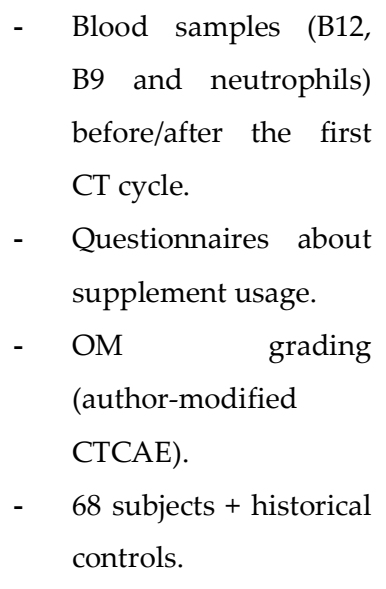 & - & No evidence on the influence was found. \\
\hline $\begin{array}{l}\text { Okada et al. } \\
\text { (2017) }\end{array}$ & 20 & $\begin{array}{l}\text { Pilot } \\
\text { single-cent } \\
\text { re RCT }\end{array}$ & $\begin{array}{l}\text { To evaluate the influence of Elental }{ }^{\circ} \\
\text { on CT-induced OM and diarrhoeas } \\
\text { in patients with oesophagic cancer. }\end{array}$ & $\begin{array}{l}\text { - } \text { IG: use of Elental }^{\circ} \text {. } \\
\text { - CG: no Elental used. } \\
\text { Questionnaires and clinical } \\
\text { examination } \\
\text { CTCAE } 4.0 \text { version }\end{array}$ & 0,5 (14 days) & Less severe OM incidence in IG. \\
\hline $\begin{array}{l}\text { De Sousa et al. } \\
\qquad(2018)\end{array}$ & 40 & $\begin{array}{l}\text { In vivo } \\
\text { study }\end{array}$ & $\begin{array}{l}\text { To evaluate the effects of glycine in } \\
\text { the expression of collagen and } \\
\text { platelet and epidermal growth } \\
\text { factors (PDGF, EGF) in a OM murine }\end{array}$ & \begin{tabular}{llr} 
& \multicolumn{1}{l}{ Control group (CG). } \\
- & Intervention $\quad$ group \\
& (IG: $\quad$ glycine \\
& supplementation).
\end{tabular} & - & $\begin{array}{l}\text { Positive effects in IG, with a better recovering rate (collagen } \\
\text { increase and growth factors reduction). }\end{array}$ \\
\hline
\end{tabular}




\begin{tabular}{|c|c|c|c|c|c|c|}
\hline & & & model. & $\begin{array}{l}\text { Measurement of collagen } \\
\text { percentage and type, EGF } \\
\text { and PDGF percentage. }\end{array}$ & & \\
\hline $\begin{array}{l}\text { Nihei et al. } \\
\text { (2018) }\end{array}$ & 67 & $\begin{array}{l}\text { Single-cent } \\
\text { re } \\
\text { RCT }\end{array}$ & $\begin{array}{l}\text { To evaluate the efficiency and safety } \\
\text { of L-Glutamine sodium azulene } \\
\text { sulphonate in the treatment of } \\
\text { CT-induced OM in patients with } \\
\text { colorectal and breast cancer. }\end{array}$ & \begin{tabular}{ll} 
- & Intervention group \\
(IG). & \\
- & Control group (CG: \\
standard & oral \\
hygiene). & \\
& \\
CTCAE 4.0 version \\
\multicolumn{2}{c}{ NRS pain scale }
\end{tabular} & 24 & $\begin{array}{l}\text { Lesser OM severity in IG. No significant differences were found } \\
\text { as for the incidence. }\end{array}$ \\
\hline $\begin{array}{l}\text { Chattopadhyay } \\
\text { et al. (2014) }\end{array}$ & 70 & $\begin{array}{c}\text { Single } \\
\text { centre RCT }\end{array}$ & $\begin{array}{l}\text { To evaluate the influence of oral } \\
\text { glutamine on RT-induced OM in } \\
\text { patients with head and neck cancer. }\end{array}$ & $\begin{array}{l}\text { - Intervention group with } \\
\text { oral glutamine (IG). } \\
\text { - No placebo control group } \\
\text { (CG). } \\
\text { WHO scale. }\end{array}$ & 8 & $\begin{array}{l}\text { Lower incidence, severity and duration of RT-induced OM in } \\
\text { IG. } \\
\text { Menor incidencia, severidad y duración de MO inducida por } \\
\text { RTen GI. }\end{array}$ \\
\hline $\begin{array}{l}\text { Üçüncü et al. } \\
\qquad(2006)\end{array}$ & 35 & $\begin{array}{l}\text { Laboratory } \\
\qquad \mathrm{CT} \\
\text { (rats) }\end{array}$ & $\begin{array}{l}\text { To determine the preventive effect of } \\
\text { Vit E (VE) and L-Carnitine (LC), } \\
\text { alone or in combination, on OM and } \\
\text { myelosuppression by RT. }\end{array}$ & $\begin{array}{ll}\text { - } & 5 \text { groups: } \\
\text { 1) } & \text { No RT (control: saline } \\
& + \text { simulated radiation). } \\
\text { 2) } & \text { RT. } \\
\text { 3) } & \text { RT+VE. } \\
\text { 4) } & \text { RT+LC. } \\
\text { 5) } & \text { RT+VE+LC. } \\
\text { - } & \text { OM measurement } \\
& \text { scale: Parkins et al. } \\
\text { - } & \text { Clinical/histopathologi }\end{array}$ & $\begin{array}{l}\text { Follow-up: } \\
4 \text { days pre-RT } \\
\text { - } 10 \text { days } \\
\text { post-RT. }\end{array}$ & $\begin{array}{l}\text { VE and LC proved to be radioprotective agents on their own } \\
\text { and not combined together, with lower severity and longer } \\
\text { time to histological appearance of OM. } \\
\text { Good tolerance and no adverse effects. }\end{array}$ \\
\hline
\end{tabular}




\begin{tabular}{|c|c|c|c|c|c|c|}
\hline & & & & $\begin{array}{l}\text { cal OM was evaluated. } \\
\text { Levels of SOD and } \\
\text { CAT (antioxidants) } \\
\text { and MDA (oxidative } \\
\text { stress indicator). }\end{array}$ & & \\
\hline $\begin{array}{l}\text { Amanat et al. } \\
\quad(2017)\end{array}$ & 82 & $\begin{array}{l}\text { Single-cent } \\
\text { re RCT }\end{array}$ & $\begin{array}{l}\text { To assess the effect of honey on } \\
\text { clinical grades of OM. }\end{array}$ & 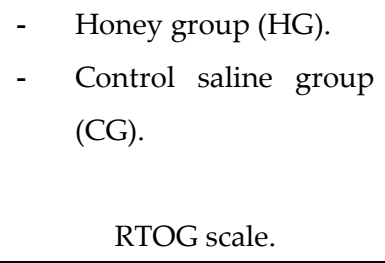 & 12 & Lower incidence and severity of OM in HG, during the RT. \\
\hline $\begin{array}{l}\text { Podlesko et al. } \\
\qquad(2018)\end{array}$ & 3 & Case series & $\begin{array}{l}\text { To evaluate the effects of topical } \\
\text { application of deoxyribonucleic acid } \\
\text { on } 3 \mathrm{OM} \text { (moderate-severe) cases in } \\
\text { patients with head and neck cancer. }\end{array}$ & $\begin{array}{l}\text { Oral spray of } \\
\text { polydeoxyribonucleotide } \\
\text { (PDRN) as treatment. }\end{array}$ & 1 & $\begin{array}{l}\text { Increased relief and remission of } \mathrm{OM} \text { as a matter of time, } \\
\text { without interruption of the treatment or opioids intake. }\end{array}$ \\
\hline $\begin{array}{l}\text { Perrone et al. } \\
\qquad(2017)\end{array}$ & 73 & $\mathrm{CT}$ & $\begin{array}{l}\text { To analyse the influence of dietary } \\
\text { supplementation with whey protein } \\
\text { concentrate (WPC) on the incidence } \\
\text { of OM in patients undergoing HSCT. }\end{array}$ & $\begin{array}{l}\text { - } \begin{array}{l}\text { WPC Group (WG). } \\
\text { - }\end{array} \text { Historical controls } \\
\text { (CG). } \\
\text { - WG was sub-stratified } \\
\text { into: consumed }<80 \% \\
\text { PWC (WG1) or } \geq 80 \% \\
\text { (WG2) of the offered } \\
\text { dose. } \\
\text { WHO and CTCAE } 4.0 \\
\text { version }\end{array}$ & Not specified & $\begin{array}{l}\text { No significant differences between WG and CG in what } \\
\text { incidence, duration and severity of MO concerns. However, in } \\
\text { WG2, shorter duration and lower incidence of severe OM was } \\
\text { found. }\end{array}$ \\
\hline $\begin{array}{l}\text { Ogata et al. } \\
\text { (2017) }\end{array}$ & 22 & $\begin{array}{c}\text { Pilot } \\
\text { prospectiv }\end{array}$ & $\begin{array}{l}\text { To evaluate the preventive effects of } \\
\text { Elental } \circledast \text { on CT-induced OM in }\end{array}$ & $\begin{array}{ll}\text { - } 22 \text { patients with } \\
\text { Elental (1 group). }\end{array}$ & 36 & Significantly reduced CT (5-FU)-induced OM grade. \\
\hline
\end{tabular}




\begin{tabular}{|c|c|c|c|c|c|c|}
\hline & & e study & $\begin{array}{l}\text { patients with colorectal cancer } \\
\text { (CRC). }\end{array}$ & CTCAE 3.0 version & & \\
\hline $\begin{array}{l}\text { Al Jouni et al. } \\
\text { (2017) }\end{array}$ & 40 & Open RCT & $\begin{array}{l}\text { To evaluate the effects of honey on } \\
\text { grade 3-4 OM, reduction of } \\
\text { bacterial/fungal infections, duration } \\
\text { of OM episodes and body weight in } \\
\text { paediatric leukaemia patients } \\
\text { undergoing CT or RT. }\end{array}$ & $\begin{array}{l}\text { - Control group (CG) } \\
\text { with Lidocaine, } \\
\text { Mycostatin, Daktarin } \\
\text { and oral cleaning. } \\
\text { - Experimental group } \\
\text { (HG) with same } \\
\text { routine as CG + honey } \\
\text { (4-6 times/day). } \\
\text { WHO scale }\end{array}$ & 12 & $\begin{array}{l}\text { Significant reduction in severity and pain in HG. Significant } \\
\text { improvement in weight and time to OM onset in HG. }\end{array}$ \\
\hline $\begin{array}{l}\text { Lopez-Vaquero } \\
\text { et al. (2017) }\end{array}$ & 49 & $\begin{array}{l}\text { Phase II } \\
\text { double-bli } \\
\text { nd RCT }\end{array}$ & $\begin{array}{l}\text { Evaluates whether glutamine is } \\
\text { effective in reducing the incidence } \\
\text { and severity of mucositis and } \\
\text { dermatitis induced by RT or CRT in } \\
\text { patients with head and neck cancer. }\end{array}$ & 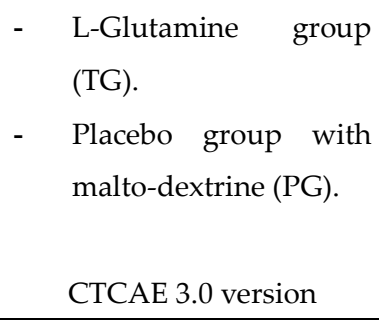 & 6 & $\begin{array}{l}\text { Incidence and severity with no significant differences between } \\
\text { groups. }\end{array}$ \\
\hline $\begin{array}{l}\text { Howlader et al. } \\
\qquad(2019)\end{array}$ & 40 & $\begin{array}{l}\text { RCT } \\
\text { (single-blin } \\
\text { ded). }\end{array}$ & $\begin{array}{l}\text { To assess whether honey improves } \\
\text { mucositis injuries and the life quality } \\
\text { of patients with RT/CT-induced OM } \\
\text { (for head and neck cancer). }\end{array}$ & $\begin{array}{l}\text { - Treatment group (HG) } \\
\text { with honey (both, } \\
\text { rinsed and ingested } \\
\text { honey). } \\
\text { - Control group (CG) } \\
\text { with saline solution. } \\
\text { CTCAE }\end{array}$ & $\begin{array}{c}\text { FromCT start } \\
-4 \text { weeksafter } \\
\text { RT. }\end{array}$ & $\begin{array}{l}\text { Less } \mathrm{OM} \text { and associated symptoms induced by } \mathrm{RT} \text { in } \mathrm{HG} \text {. } \\
\text { Shorter time towards the recovery of a regular life quality . }\end{array}$ \\
\hline Elsass, F.T. & 10 & Case series & The aim was to improve OM (oral & Application of honey & - & Shorter healing time with lower pain rate in all cases. \\
\hline
\end{tabular}




\begin{tabular}{|c|c|c|c|c|c|c|}
\hline$(2017)$ & $\begin{array}{c}\text { (3 } \\
\text { analyze } \\
\text { d) }\end{array}$ & & $\begin{array}{l}\text { comfort and feeding) with standard } \\
\text { oral care and the use of } \\
\text { Leptospermum honey in paediatric } \\
\text { oncology patients after proven CT. }\end{array}$ & $\begin{array}{l}\text { on the buccal surface } \\
\text { with a cotton swab, } 3 \\
\text { times/day. Then spat } \\
\text { or sucked out. }\end{array}$ & & \\
\hline $\begin{array}{l}\text { Elkerm y } \\
\text { Tawashi (2014) }\end{array}$ & 20 & Pilot study & $\begin{array}{l}\text { To evaluate whether date palm } \\
\text { pollen (DPP) can be effective in the } \\
\text { prevention and treatment of RT and } \\
\text { CT-induced OM in patients with } \\
\text { head and neck cancer. }\end{array}$ & $\begin{array}{l}\text { - DPP Group (one daily } \\
\text { suspension). } \\
\text { - Control group (CG) } \\
\text { (antifungal, } \\
\text { rebamipide and oral } \\
\text { analgesia). } \\
\text { OMAS score and visual } \\
\text { analogue scale for mouth } \\
\text { pain and dysphagia. }\end{array}$ & 1.5 (6 weeks) & $\begin{array}{l}\text { Significant reduction in incidence, severity and pain in OM and } \\
\text { dysphagia in DPP. }\end{array}$ \\
\hline $\begin{array}{l}\text { Raeessi et al. } \\
\qquad(2014)\end{array}$ & 61 & $\begin{array}{l}\text { Single-cent } \\
\text { re } \\
\text { double-bli } \\
\text { nd RCT }\end{array}$ & $\begin{array}{l}\text { To evaluate the effects of coffee }+ \\
\text { honey in the treatment of OM by CT } \\
\text { and to compare them with the effects } \\
\text { of steroids. }\end{array}$ & $\begin{array}{l}3 \text { grupos: } \\
\text { - } \quad \text { Betamethasone group } \\
\text { (EG). } \\
\text { - } \quad \text { Honey group (HG). } \\
\text { - } \quad \text { Honey + coffee group } \\
\text { (HCG). } \\
\text { WHO scale }\end{array}$ & $\begin{array}{c}36 \\
2011-2013\end{array}$ & Significant reduction in the severity of MO in all three groups. \\
\hline $\begin{array}{l}\text { Baydar et al. } \\
\qquad(2005)\end{array}$ & 99 & $\mathrm{CT}$ & $\begin{array}{l}\text { To research the effects of local } \\
\text { cryotherapy on the prevention of } \mathrm{CT} \\
(5-\mathrm{FU}) \text {-induced OM. }\end{array}$ & $\begin{array}{l}\text { - Intervention Group } \\
\text { (IG): CT courses with } \\
\text { local cryotherapy (ice } \\
\text { in the mouth during } \\
\text { the CT course up to } 10\end{array}$ & Not specified. & 5-FU-induced OM incidence lower in GI (OR=11.5). \\
\hline
\end{tabular}




\begin{tabular}{|c|c|c|c|c|c|c|}
\hline & & & & $\begin{array}{l}\text { minutes afterwards). } \\
\text { - Control Group (CG): } \\
\text { no-cryotherapy } \\
\text { courses. }\end{array}$ & & \\
\hline $\begin{array}{l}\text { Peterson et al. } \\
\qquad(2007)\end{array}$ & 305 & $\begin{array}{l}\text { Phase III, } \\
\text { double-bli } \\
\text { nd RCT }\end{array}$ & $\begin{array}{l}\text { To observe the efficacy of Saforis }{ }^{\circledR} \text { in } \\
\text { the prevention and treatment of } \mathrm{OM} \\
\text { caused by CT treatment in breast } \\
\text { cancer. }\end{array}$ & 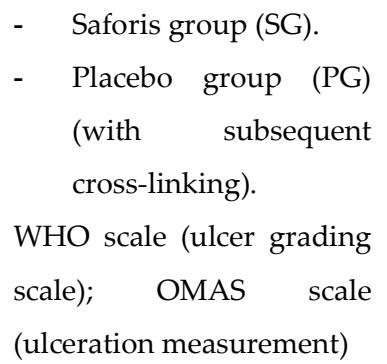 & Not specified. & Lower severity and incidence rate in SG. \\
\hline $\begin{array}{l}\text { Fogh et al. } \\
\text { (2016) }\end{array}$ & 119 & $\begin{array}{l}\text { Multicentri } \\
\text { c phase II } \\
\text { RCT }\end{array}$ & $\begin{array}{l}\text { To evaluate the effect of Manuka } \\
\text { honey (liquid and tablets) in the } \\
\text { prevention of RT-induced } \\
\text { oesophagitis in lung cancer patients. }\end{array}$ & $\begin{array}{l}\text { - G1: Manuka honey } \\
\text { (liquid). } \\
\text { - G2: Manuka honey } \\
\text { (tablets). } \\
\text { - G3: control, standard } \\
\text { care. } \\
\text { Measurements: } \\
\text { odynophagia (NRPS scale), } \\
\text { pain, opioid use, } \\
\text { dysphagia, weight loss, } \\
\text { quality of life and } \\
\text { nutritional status. }\end{array}$ & 12 & $\begin{array}{l}\text { There were no significant differences for groups G1, G2 or G3, } \\
\text { so the use of honey did not prove to be superior to standard } \\
\text { health care. }\end{array}$ \\
\hline $\begin{array}{l}\text { Samdariya et al. } \\
\qquad(2015)\end{array}$ & 69 & Open RCT & $\begin{array}{l}\text { To study the intake of honey in pain } \\
\text { relief caused by RT-induced OM in } \\
\text { patients with head and neck cancer. }\end{array}$ & $\begin{array}{l}\text { A. Gargle with soda and } \\
\text { benzidamine (PG). } \\
\text { B. Gargle with soda + } \\
\text { benzidamine + honey }\end{array}$ & $\begin{array}{l}\text { Nov. } 2011- \\
\text { Jan. } 2013 .\end{array}$ & $\begin{array}{l}\text { Slightly greater relief in HG during the entire follow-up (3 } \\
\text { months), with a significant reduction in the severity of } \\
\text { OM-associated pain and fewer treatment interruptions. }\end{array}$ \\
\hline
\end{tabular}




\begin{tabular}{|c|c|c|c|c|c|c|}
\hline & & & & (HG). & & \\
\hline $\begin{array}{l}\text { Matsuda et al. } \\
\qquad \text { (2015) }\end{array}$ & 90 & $\begin{array}{c}\text { Double-bli } \\
\text { nd phase } \\
\text { III RCT. }\end{array}$ & $\begin{array}{l}\text { To research whether TJ-14 } \\
\text { (Hangeshashinto) prevents and/or } \\
\text { controls CT-induced OM in patients } \\
\text { with colorectal cancer. }\end{array}$ & $\begin{array}{l}\text { - } \quad \text { TJ-14 treatment group } \\
\text { (IG). } \\
\text { - Placebo group (PG). } \\
\text { WHO scale. }\end{array}$ & 0,5 (14 days). & $\begin{array}{l}\text { Significant reduction in the duration of severe OM, with no } \\
\text { effect on the severity or incidence of } \mathrm{OM} \text { itself. }\end{array}$ \\
\hline $\begin{array}{l}\text { Bateman et al. } \\
\qquad \text { (2013) }\end{array}$ & $\begin{array}{c}\text { It isn't } \\
\text { especifi } \\
\text { ed } \\
\text { (aproxi } \\
\text { mate } \\
\text { number } \\
=48 \text { ). }\end{array}$ & $\begin{array}{c}\text { Laboratory } \\
\text { in vivo } \\
\text { study }\end{array}$ & $\begin{array}{l}\text { To investigate the protective effects } \\
\text { of nutritional drinks on the } \\
\text { development of methotrexate } \\
\text { (MTX)-induced gastrointestinal } \\
\text { mucositis in animals with and } \\
\text { without cancer. }\end{array}$ & $\begin{array}{l}\text { - G1: ClinutrenProtect }{ }^{\circledR} \\
\text { (whey protein, } \\
\text { short-chain fatty acids, } \\
\text { TGF-b, L-glutamine). } \\
\text { G2: IMPACT } \\
\text { AdvancedRecovery }{ }^{\circledR} \\
\text { (whey protein, } \\
\text { medium chain fatty } \\
\text { acids, arginine, } \\
\text { nucleotides and } \\
\text { polyunsaturated fatty } \\
\text { acids). } \\
\text { G3: placebo (drink). } \\
\text { Control: standard rat diet. }\end{array}$ & Not specified. & $\begin{array}{l}\text { No protection of the administered diets against MTX-induced } \\
\text { mucositis was observed. }\end{array}$ \\
\hline $\begin{array}{c}\text { Jayachandran y } \\
\text { Balaji (2012) }\end{array}$ & 60 & $\mathrm{RCT}$ & $\begin{array}{l}\text { To evaluate the effect of natural } \\
\text { honey and benzidamine } \\
\text { hydrochloride on the development } \\
\text { and severity of RT-associated OM in } \\
\text { patients with oral cancers. }\end{array}$ & $\begin{array}{l}3 \text { grupos (oral rinses): } \\
\text { A. Honey }(\mathrm{HG}) \text {. } \\
\text { B. Benzidamine } \\
\text { hydrochloride (BG). } \\
\text { C. Saline } 0^{\prime} 9 \% \text { (control } \\
\text { group, } \mathrm{CG}) .\end{array}$ & 6 & Lower severity and earlier healing of OM not significant in HG. \\
\hline
\end{tabular}




\begin{tabular}{|c|c|c|c|c|c|c|}
\hline $\begin{array}{l}\text { Sugita et al. } \\
\text { (2012) }\end{array}$ & 118 & $\begin{array}{l}\text { Retrospecti } \\
\qquad \text { ve CT }\end{array}$ & $\begin{array}{l}\text { To ascertain the effects of folinic acid } \\
\text { administration (systemic and rinsed) } \\
\text { on the incidence of OM and acute } \\
\text { graft-versus-host disease (GVHD) } \\
\text { after GVHD prophylaxis with MTX } \\
\text { in patients undergoing HSCT. }\end{array}$ & $\begin{array}{l}\text { Systemic folic acid } \\
\text { was administered to } \\
\text { patients at increased } \\
\text { risk of developing OM } \\
(\mathrm{n}=29) .\end{array}$ & 48 & $\begin{array}{l}\text { It could be useful in reducing the incidence of severe OM, both } \\
\text { in systemic use and rinsed. }\end{array}$ \\
\hline $\begin{array}{l}\text { Sorensen et al. } \\
\qquad(2008)\end{array}$ & 206 & $\begin{array}{l}\text { Double-bli } \\
\text { nd RCT }\end{array}$ & $\begin{array}{l}\text { To evaluate prevention of OM using } \\
\text { chlorhexidine compared to } \\
\text { cryotherapy during } 5 \text {-FU CT } \quad \text { in } \\
\text { gastrointestinal cancer. }\end{array}$ & $\begin{array}{l}3 \text { groups: } \\
\text { A. Chlorhexidine rinse } \\
\text { (IG). } \\
\text { B. Placebo rinse (saline) } \\
\text { (PG). } \\
\text { C. Cryotherapy (CG). }\end{array}$ & - & $\begin{array}{l}\text { Higher severity rate of OM in PG and lower in CG, with a } \\
\text { lower incidence and duration in IG and CG than in PG, } \\
\text { therefore prophylaxis seems effective in both IG and CG. }\end{array}$ \\
\hline Das et al. (2011) & 52 & RCT & $\begin{array}{l}\text { Observe protective/healing effect } \\
\text { against RT and CT effects }(\mathrm{OM} \text {, skin } \\
\text { reaction, xerostomia or voice } \\
\text { changes) when using Glycyrrhiza } \\
\text { glabra. }\end{array}$ & $\begin{array}{l}\text { 4 groups: } \\
\text { A. Glycyrrhiza + local } \\
\text { honey and oral } \\
\text { Glycyrrhiza(GLHG). } \\
\text { B. Glycyrrhiza+ lcoal } \\
\text { honey (LHG). } \\
\text { C. Topical honey (HG). } \\
\text { D. Control (conventional } \\
\text { modern medication) } \\
\text { (CG). }\end{array}$ & 1.75 (7 weeks) & $\begin{array}{l}\text { Lower incidence and severity in GLHG and LHG compared to } \\
\text { CG, but similar to HG. }\end{array}$ \\
\hline $\begin{array}{l}\text { Thornley et al. } \\
\qquad(2004)\end{array}$ & 37 & CT & $\begin{array}{l}\text { To determine the feasibility and } \\
\text { potential efficacy of a fixed } \\
\text { combination of agents in reducing } \\
\text { RRT (regimen-related toxicity) in } \\
\text { children undergoing HSCT. }\end{array}$ & $\begin{array}{l}\text { - Combination group of } \\
\text { ursodeoxycholic acid } \\
\text { (UDCA), vitamin E, } \\
\text { folinic acid and } \\
\text { titrated parenteral } \\
\text { nutrition (IG). }\end{array}$ & 36 & Significant decrease in the incidence and severity of OM in IG. \\
\hline
\end{tabular}




\begin{tabular}{|c|c|c|c|c|c|c|}
\hline & & & & $\begin{array}{lr}\text { - } & \text { Historical } \\
\text { group } & \text { controls } \\
(\text { PG) } & \end{array}$ & & \\
\hline $\begin{array}{l}\text { Iyama et al. } \\
\qquad(2014)\end{array}$ & 44 & RCT & $\begin{array}{l}\text { To research whether } \\
\text { supplementation with GFO } \\
\text { (Glutamine, Fibre, Oligosaccharides) } \\
\text { decreases the severity of mucosal } \\
\text { injury post-HSCT. }\end{array}$ & $\begin{array}{l}\text { - } \quad \text { GFO group (IG). } \\
\text { - Control (CG). } \\
\text { CTCAE } 4.0 \text { version }\end{array}$ & 36 & Significant decrease in OM and higher survival rate in IG. \\
\hline $\begin{array}{l}\text { Takano et al. } \\
\qquad \text { (2015) }\end{array}$ & $\begin{array}{c}96 \\
\text { pocillos }\end{array}$ & $\begin{array}{l}\text { In vitro } \\
\text { study }\end{array}$ & $\begin{array}{l}\text { To investigate whether } \gamma \text {-tocotrienol } \\
\text { (vitamin E) can enhance survival of } \\
\text { oral human keratinocytes (RT7) } \\
\text { against 5-FU-induced cell toxicity. }\end{array}$ & $\begin{array}{l}\text { RT7 cells were treated } \\
\text { with 5-FU and } \\
\gamma \text {-tocotrienol. } \\
\text { - } 4 \text { groups: } \\
\text { A: } \gamma \text {-tocotrienol. } \\
\text { B: 5-FU. } \\
\text { C: } \gamma \text {-tocotrienol + 5-FU. } \\
\text { D: Control de 5-FU + } \\
\text { N-acetylcysteine. }\end{array}$ & - & $\begin{array}{l}\text { In } \mathrm{C} \text { there was a significant inhibition of ROS production } \\
\text { induced by } 5 \text {-FU. }\end{array}$ \\
\hline $\begin{array}{l}\text { Agha-Hosseini } \\
\text { et al. (2021) }\end{array}$ & 59 & $\begin{array}{l}\text { Triple-blin } \\
\text { d RCT }\end{array}$ & $\begin{array}{l}\text { To evaluate whether a vitamin } \mathrm{E} \text {, } \\
\text { hyaluronic acid and triamcinolone } \\
\text { mouthwash is effective in the } \\
\text { treatment of radiotherapy-induced } \\
\text { OM grades 3-4. }\end{array}$ & 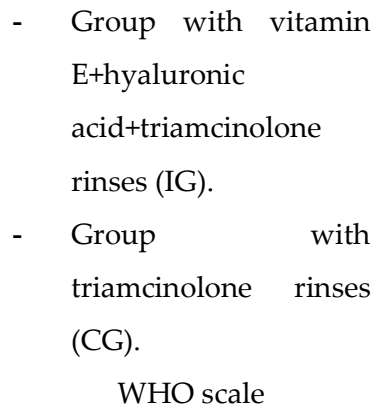 & 4 weeks & $\begin{array}{l}\text { Significant reduction in the severity of RT-induced OM in IG } \\
\text { overtime. }\end{array}$ \\
\hline
\end{tabular}




\begin{tabular}{|c|c|c|c|c|c|c|}
\hline $\begin{array}{l}\text { Yeshurun et al. } \\
\qquad(2020)\end{array}$ & 52 & $\begin{array}{l}\text { Multicentri } \\
\text { c double } \\
\text { blind RCT }\end{array}$ & $\begin{array}{l}\text { To determine whether folinic acid } \\
\text { (FA) reduces methotrexate } \\
\text { (MTX)-induced toxicity in patients } \\
\text { undergoing myeloablative } \\
\text { conditioning (CM) for allogeneic } \\
\text { haematopoietic cell transplantation, } \\
\text { who have as well received MTX } \\
\text { prophylaxis for graft-versus-host } \\
\text { disease. }\end{array}$ & $\begin{array}{l}\text { - } \quad \text { TGwith FA } \\
\text { - } \quad \text { PGwith placebo. } \\
\text { WHO scale }\end{array}$ & $17(4.5-50)$ & $\begin{array}{l}\text { There were no significant TG and PG differences in incidence, } \\
\text { duration or severity of OM. }\end{array}$ \\
\hline $\begin{array}{l}\text { Pattanakitsakul } \\
\text { et al. (2020) }\end{array}$ & 30 & $\begin{array}{l}\text { Preliminar } \\
\text { and } \\
\text { unicentric } \\
\text { quasi-rand } \\
\text { omized } \\
\text { trial }\end{array}$ & $\begin{array}{l}\text { To examine the protective effect of } \\
\text { vitamin A supplementation against } \\
\text { mucosal damage of the } \\
\text { gastrointestinal tract after CT in } \\
\text { paediatric patients undergoing } \\
\text { HSCT. As a secondary objective, to } \\
\text { assess the occurrence of OM. }\end{array}$ & $\begin{array}{l}\text { - } \text { TG with single dose } \\
\text { (200000UI) of vitamin } \\
\text { A. } \\
\text { - PGwithout vitamin A } \\
\text { WHO scale }\end{array}$ & 12 & $\begin{array}{l}\text { There were no significant differences in incidence or severity of } \\
\text { OM. }\end{array}$ \\
\hline
\end{tabular}




\section{Discussion}

PEDIATRIC EVIDENCE.

Al Jaouni et al. (2017), throughout an open clinical trial, determined that honey diminished the incidence of the worst oral mucositis grades and delayed its onset. It was also encountered that honey helped to decrease pain, infections and hospital stay. Furthermore, increase patients weight compared with the control group. In contrast, Widjaja et al. (2020), with their double-blind randomized controlled trial showed less incidence of $\mathrm{OM}$ in their treatment group with glutamine, proving other results such as a decrease in the severity of OM due to the glutamine and less time of treatments and sanitary costs.

Alternatively, Thornley et al. (2004) demonstrated an OM incidence and severity reduction along with less regimen-related toxicity (especially in high-risk patients) thanks to a preparation made of ursodeoxycholic acid, vitamin E, folinic acid and parenteral nutrition as prevention. In contrast, Pattanakitsakul et al. (2020) proved in their preliminary quasi-randomized trial that vitamin A did not prevent OM.

Oosterom et al. (2019) in their cohort study evidenced that basal vitamin D levels were not related with MTX induced OM, but it was found an association (OR=1.26) between the reduction in vitamin D levels during MTX treatment with severe OM (grade 3 or more). Finally, a case series (3) reported the benefits of honey as OM treatment in patients undergoing chemotherapy.

Sung et al. (2015) carried out a clinical practice guideline where they collected all the available evidence about glutamine (and other treatments) to prevent OM in paediatric patients undergoing a conditioning regimen previous to a hematopoietic stem cell transplantation, and they determined that there was no consistency on the reduction of $\mathrm{OM}$ in more than one study. The only retrieved study about glutamine in paediatric patients on this paper reveals a change, given that it could be determined that this clinical trial is consistent evidence of the effectiveness of glutamine to decrease the incidence of $\mathrm{OM}$, highlighting that more studies are needed to consider it as a recommendation (Widjaja et al., 2020).

In addition, the same Sung et al. (2015) established in their review that topical vitamin $\mathrm{E}$ did not demonstrate to reduce OM effectively. In the present study, it was not possible to compare the retrieved article with Sung et al. (2015) review since it was applied a combination of agents. Nevertheless, it must be emphasised the huge lack of studies with vitamins, it is necessary to identify their effect and implement recommendations based on sufficient data (Thornley et al., 2004).

The cohort study with vitamin D was not possible to compare with others because of the inexistence of more papers, corroborating the previous paragraph about the lack of evidence in this subject (Oosterom et al., 2019).

Friend et al. (2018) clarified in their review that honey could be effective in the treatment and prevention of $\mathrm{OM}$ in paediatric patients in limited resources areas, but determines that there is no available evidence that compares if honey is even or more effective than the established treatments. Evidence found in this study supports this affirmation since the open clinical trial shows the efficacy of honey in OM, but there are no comparative studies between honey and other treatments. Also, case series don't have that strong evidence to be compared with clinical trials or to state conclusions if more evidence doesn't exist (Al Jaouni et al., 2017).

\section{GLUTAMINE}

Regarding adults and the use of glutamine, Nihei et al. (2018), Chattopadhyay et al. (2014) and López-Vaquero et al. (2017) in their scientific studies didn't show a reduction in the total incidence of OM. In contrast, Huang et al. (2019) and Tanaka et al. (2016) evidenced a reduction in the total incidence of OM; this matches the contribution of a cohort study made by Pachón et al. (2018), except for the fact that they didn't report less incidence in the severity of OM (grade $\geq 2$ ). The trials of Huang et al. (2019) and López-Vaquero et al. (2017) got the same result on this matter, contrasting with the re- 
sults of Tsujimoto et al. (2015), Tanaka et al. (2016), Nihei et al. (2018) and Chattopadhyay et al. (2014) who observed less severity of OM in patients treated with glutamine.

Concerning the time of onset of OM, only three papers addressed this topic, and two of them determined an absence of delay in the onset of OM, contrarily to what Chattopadhyay et al. (2014) study addressed (Tsujimoto et al., 2015; López-Vaquero et al., 2017). As for the duration of OM, it was studied in four trials, proven in two of them a reduction in the duration of the most severe OM (Chattopadhyay et al. 2014; Iyama et al. 2014).

Other nutritional factors, such as weight, were studied in five scientific articles, showing a tendency in weight loss slightly minor in those groups with glutamine. Also, Tanaka et al. (2016) proved the maintenance of weight in cancer patients when it was mixed glutamine and elemental diet (Iyama et al., 2014; Chang et al., 2019; Cho et al., 2019; Pathak et al., 2019).

Quality of life (QoL) was evaluated by López-Vaquero et al. (2017) through an adapted questionnaire for this topic without obtaining a link between the use of glutamine and OM patients' quality of life. Other factors such as pain and the use of analgesia (3 articles), dysphagia (1 article) and odynophagia (1 article) were studied. The results provided determined that the treatment with glutamine improved dysphagia, odynophagia and pain, showing two of them a decrease in analgesia use too (Tsujimoto et al., 2015; Nihei et al. (2018); Pachón et al., 2018; Pathak et al., 2019).

Four of the trials delved into a product called Elental®, a liquid dietetic formula enriched with amino acids and a source of L-glutamine. The results showed at large a reduction in the severity of $\mathrm{OM}$ in groups treated with Elental ${ }^{\circledR}$, highlighting the investigation of Harada et al. (2019), who proved a decrease in the administered analgesia and CRP levels (4-6 weeks of CRT). These results concur with the ones obtained by Harada et al. (2018) in their in vivo study in which rats treated with Elental@ healed more rapidly of OM ulcers (Ogata et al., 2016; Okada et al. 2017; Tanaka et al., 2018).

About its combination with other products, Peterson et al. (2007) analyzed a compound called Saforis ${ }^{\circledR}$ (an oral formulation that increases the availability of glutamine in the oral cavity), which proved to decrease the severity of antineoplastic induced OM, with no other conclusive results to report. Finally, Bateman et al. (2013) used a combination of WHEY protein, fatty acid and glutamine, showing that this doesn't protect against $\mathrm{OM}$ in rats. Nevertheless, Anderson and Lalla (2020) performed a review where they suggested glutamine rinses (liquid formula) in patients with head and neck cancers undergoing CRT since they found that it decreases the severity and duration of OM and oesophagitis. This is comparable to five of the found studies in the bibliographic search, even though all of them study oral glutamine to rinse and afterwards swallowing, revealing the same benefits reported in the commented review. Oral glutamine might be beneficial for both topical and by ingestion, but it should be further studied since the body of evidence must be larger to recommend rinses or the intake of glutamine (Chattopadhyay et al., 2014;Tsujimoto et al., 2015; López-Vaquero et al., 2017; Pachón et al., 2018; Huang et al., 2019).

In addition, recently Shuai et al. (2020) published a meta-analysis where affirmed that oral glutamine could have no clinical benefits in the prevention and/or treatment in CRT or RT induced OM in patients with head and neck cancers. Therefore, glutamine should be studied further in order to obtain more consistent results.

\section{HONEY}

Severity is the most studied aspect of honey use. It has been proven that honey is effective in the eventual reduction of the severity of OM, as Howlader et al. (2019), Rao et al. (2017) and Amanat et al. (2017) point out in their scientific publications.

Along the same lines, Raeessi et al. (2014) indicated that the efficacy of the combination between honey and coffee to decrease the severity of OM exceed the same capacity of honey by itself and steroids. On the other hand, Fogh et al. (2016) delved into the severity of oesophagitis and they did not find a link between honey and the decrease of OM 
stage. This same study does not highlight the association between honey and a reduction of late forms of odynophagia (it doesn't occur in the same way in precocious forms).

Rao et al. (2017) approaches the incidence of OM and proves the benefits of honey in the prevention and delay of the onset of OM. Also, they showed a reduction in weight loss in their treatment group with this compound. Jayachandran y Balaji (2012) also observed a delay in the onset of $\mathrm{OM}$ in patients treated with honey in comparison to those who were treated with benzydamine; in fact, no effects were found on the duration.

Regarding other parameters analysed, only Howlader's et al. (2019) publication assesses the influence of honey on the quality of life (QoL) during OM, being observed a late improvement of OM because of this. The trial performed by Samdariya et al. (2015) showed a consistent decrease in the severity of the pain, resulting in fewer discontinuances in RT.

As a final remark, Anturlikar et al. (2019) in their in vitro and in vivo study with a combination of turmeric, Triphala and honey (HTOR-091516) showed positive results such as low product toxicity, inflammation inhibition (TNF- $\alpha$ ) and a protector effect in CT induced OM.

Münstedt y Männle (2019) in their review evaluating the use of honey as OM treatment showed a decrease in the severity of the ulcers which harmonize with the scientific articles found in the present paper and in the systematic review and meta-analysis made by Tian et al. (2020).

Other aspects mentioned by Tian et al. (2020) include the indication of a potential decrease in the incidence of OM during the treatment with honey, however, from the present study, only one study proves significant prevention.

There exist other interesting aspects such as OM pain reduction and the inhibition of the inflammatory pathways (in vitro study with "HTOR-091516") which are not comparable with the mentioned reviews, since there is no evidence to suggest or recommend the use of honey in this aspects. Even though honey could be useful to reduce mucositis severity, the rest of the aspects should be studied more in-depth to provide reliable data and determine suggestions and recommendations on this matter.

VITAMINS AND AMINO ACIDS.

The most important results of the three retrieved clinical trials showed a reduction in the severity of $\mathrm{OM}$ in patients treated with a combination of GeneTime $($, group B vitamin complex, Oncoxin@ (combination of vitamin C, B6 and amino acids) and vitamin B9, proving a reduction in mucositis incidence too. Nevertheless, Branda et al. (2004) in their cohort study didn't find a link between the quantity of vitamins B12, B9 and multivitamins supplements with this severity (Sugita et al., 2012; Shumsky et al., 2019; Sun et al., 2019).

Specifically, Oncoxin $(\subseteq$ was related to a weight increase and a normal intake too. On the one hand, the combination of GeneTime $($ and vitamin B proved less pain and quicker healing of OM ulcers. Finally, the treatment with vitamin B9 coincide with the effect of Oncoxin $($ in the improvement of the intake capacity, but it didn't show a reduction in parenteral nutrition use of time; it did show a reduction of opioid use (Sugita et al., 2012; Shumsky et al., 2019; Sun et al., 2019).

On the other hand, Nejatinamini et al. (2018) showed that the decrease in the blood levels of vitamins A and D during RT are related to OM. In the same way, an in vitro study determined relevant information since it showed that vitamin $\mathrm{E}$ ( $\gamma$-tocotrienol) in CT fosters the survival of oral human keratinocytes through the inhibition of reactive oxygen species (ROS), probably by the suppression of Nrf2 route (Takano et al., 2015).

Recently, a clinical trial published by Agha-Hosseini et al. (2021) with a rinse made of vitamin E, hyaluronic acid and triamcinolone proved to be useful in the treatment of OM. Similarly, another scientific group did a clinical trial with folinic acid for the prevention of OM. However, their results did not prove to be very successful (Yeshurun et al. 2020). 
Related to the use of complete protein, the study of Perrone et al. (2017) proved that there was not a link between the intake of concentrated WHEY protein and the incidence, severity and duration of OM. However, the individuals who took more quantity of WHEY protein presented less severity and duration of OM compared to those who took less quantity of protein. Finally, De Sousa's et al. (2018) in vivo study indicated that glycine promoted major and better tissue restructuring.

Regarding non-combined amino acids, a clinical trial and an in vivo laboratory study are highlighted. The rest of the studies related to amino acids ( 3 in total) appear in combination with other nutritional compounds and have already been mentioned.

Yarom et al. (2019) considered that vitamin B9 could not be effective in the prevention of OM in patients who receive therapy for a posterior hematopoietic stem cell transplantation, highlighting a cohort study (which is also analyzed in this study) that proves the efficacy in the reduction of both total incidence and OM severity in patients undergoing CT for a posterior stem cell transplantation. There exist few studies related to vitamin B9 to determine some evidence about it.

Evidence void also occurs when it is studied the treatment of OM with vitamins E and D since both have some studies (5 about vitamin E and 1 about vitamin D) which determine different effects about OM and cannot be compared between them due to the characteristics used to analyze each study (they use different laboratories, cohorts, clinical trials...). Therefore, supporting what Yarom et al. (2019) mention in their review, it is not possible to determine consistent evidence for the use of vitamins.

In this section, when it comes to analyze the use of amino acids, it is highlighted that there are not reviews about the use of Glicine and concentrated WHEY protein. As a result, there is a lack of evidence in this study ( 2 articles, one of each of the topics) to determine whether they could be useful in treating OM.

\section{GLYCYRRHIZA GLABRA.}

On the one hand, the study of Mamgain et al. (2020) and Das et al. (2011) found both a reduction in incidence and severity in those groups treated with liquorice (Glycyrrhiza glabra), with more effect than those treated with honey in the same trial. Contrastingly, Matsuda et al. (2015) proved that the use of Hangeshashinto (mixed with 7 medicinal plants, Glycyrrhiza glabra among them) does not affect the incidence and stage of OM, but it does affect in the duration of severe OM.

Finally, highlight that Das et al. (2011) also found fewer interruptions in the treatment and persistence of xerostomia despite liquorice administration.

OM therapy with liquorice is novel and not so much researched. In the present study, there were only the articles analyzed about this compound, making it insufficient to determine clear evidence or preventive and/or healing effect in OM. Richard (2021) proves in their review that glycyrrhizin and glycyrrhetinic acids have anti-inflammatory properties, inhibiting specifically interleukin secretion (IL-6, IL-2, IL-12...), the expression of TNF- $\alpha$ and cytokine cascade, among others.

Even though this literature review does not focus on OM specifically, attention could be drawn towards this matter, since physiopathologically a lot of inflammatory routes are involved in the production of oral ulcers, and compounds such as liquorice (with antiinflammatory properties) could give results in the inhibition of inflammatory routes if further research is carried out in the future .

OTHERS.

Elkerm y Tawashi (2014) delved into the part of date pal pollen in OM treatment through a preliminary study. Such research showed a reduction in the incidence and severity of RT induced OM. It was also proven a reduction in the pain and dysphagia during OM.

Secondly, deoxyribonucleic acid was studied by Podlesko et al. (2018), using it as a topical spray in a case series. The results showed pain relief and quicker healing on OM ulcers in two cases and a deterioration in the third one. 
López-González et al. (2021) proves the efficacy to prevent and treat OM through oral cryotherapy. This evidence was also found in several clinical practice guidelines, highlighting its best utility in the prevention of OM in patients treated with $\mathrm{CT}$. The present study cannot compare the results of the given evidence due to the scarceness of the analysis ( 2 articles), but it does agree with the results found in the evidence retrieved from other reviews and clinical practice guidelines (Peterson et al., 2011; Lalla et al., 2014; Elad et al., 2020).

\section{STRENGTHS}

The performance of this paper allows the gathering of information related to a not so studied topic, opening at the same time future doors to investigations about this subject and evidencing the need for more scientific literature about this pathological entity, prevalent between oncological patients.

In the same way, carrying out this review helps to prove which is the best available evidence on OM nutritional treatment (either prophylactic or for a treatment itself). Likewise, it facilitates a guide for health professionals involved in the patient care process such as dietitian-nutritionists, nurses and doctors.

LIMITATIONS (Weaknesses)

Some methodologic limitations must be highlighted in the present study. On the one hand, the available time to carry out this review was highly limited (from October to February), affecting the extension of the bibliographic search. On the other hand, a context limitation was present since it was noted the lack of consensus in the use of OM grading scales in the different scientific articles, making it impossible to compare the articles between them even though they assessed the same nutritional compounds.

Lastly, nutritional interventions in this entity aren't studied as much as they must be studied, therefore, there is not enough scientific literature to affirm solid conclusions, requiring more support with further research articles.

\section{Conclusions}

In paediatric ages, positive results are found for the treatment and/or prevention of $\mathrm{OM}$, but it is needed more investigation since it does exist an evidence void for the use of all the studied nutritional compounds.

Regarding to the adults population, glutamine and honey could be the most useful treatment for OM, but more evidence is needed to confirm a reduction in the severity. In vitamins and amino acids (different from glutamine), little evidence exists. It seems like vitamins could serve as a treatment, but there is scarce evidence and generally, the investigated formulations don't only include vitamins, making it difficult to prove their effects on their own.

It is not possible to present the usefulness of Glycyrrhiza glabra, date palm pollen and polydeoxyribonucleotides in the prevention and/or treatment of $\mathrm{OM}$ in oncological patients due to a lack of evidence. Moreover, cryotherapy was also analyzed insufficiently in this study, contrasting with what was found in the scientific literature.

In general, very few scientific productions exist about the nutritional approach of CT and/or RT induced OM in cancer patients even though the high interest of the study for being an alternative treatment is highly attainable and easily available.

Author Contributions:... BGG and LCA developed the concept. BGG wrote the manuscript and LCA critically appraised the document at all stages. All authors critically reviewed, read and agreed to the published version of the manuscript.

Funding: This research received no external funding.

Conflicts of Interest: The authors declare no conflict of interest.

\section{References}


3. Latest global cancer data: Cancer burden rises to 18.1 million new cases and 9.6 million cancer deaths in 2018. Available online: https://www.who.int/cancer/PRGlobocanFinal.pdf (12 of September 2018).

4. Efectos secundarios de la quimioterapia. Available online: https://www.cancer.org/content/dam/CRC/PDF/Public/8459.96.pdf (22 of November 2019).

5. Wardley, A.M., Jayson, G.C., Swindell, R., Morgenstern, G.R., Chang, J., Bloor, R., Fraser, C.J., \&Scarffe, J.H. Prospective evaluation of oral mucositis in patients receiving myeloablative conditioning regimens and haemopoietic progenitor rescue. BJHaem2001,110,292-299. https://doi.org/10.1046/j.1365-2141.2000.02202.x

6. $\quad$ Robien, K.; Schubert, M.M.;Bruemmer, B.; Lloid, M.E.; Potter, J.D.; \& Ulrich, C.M. Predictors of oral mucositis in patients receiving hematopoietic cell transplants for chronic myelogenous leukemia. JCO2004,22, 3408-3419. DOI: $10.1200 /$ ICO.2004.05.147

7. Sonis, S.; Antin, J.;Tedaldi, M.;\&Alterovitz, G.SNP-based Bayesian networks can predict oral mucositis risk in autologous stem cell transplant recipients. Oral Dis 2013,19, 721-727. https://doi.org/10.1111/odi.12146

8. Lalla, R.V.; Bowen, J.; Barasch, A.; Elting, L.; Epstein, J.; Keefe, D.M.; McGuire, D.B.; Migliorati, C.; Nicolatou-Galitis, O.; Peterson, D.E.;Raber-Durlacher, J.E.; Sonis, S.T.; Elad, S.;\& The Mucositis Guidelines Leadership Group of the Multinational Association of Supportive Care in Cancer and International Society of Oral Oncology (MASCC=ISOO). Cancer 2014, 120,1453-1461. https://doi.org/10.1002/cncr.28592

9. Al-Ansari, S.; Zecha, J. A.; Barasch, A.; de Lange, J.; Rozema, F. R.;\& RaberDurlacher, J. E. Oral Mucositis Induced By Anticancer Therapies. Curr Oral Health Rep2015, 2,202-211. https://doi.org/10.1007/s40496-015- 0069-4

10. Trancoso Estrada, J. Capítulo 11: Enfermedades del aparato digestivo. In Manual de codificación CIE-10-ES diagnósticos, 2018 ed.; Pastor, M.D., Ed.; Ministerio de Sanidad, Servicios Sociales e Igualdad: Madrid, España, 2018 ; p.161. https://www.mscbs.gob.es/estadEstudios/estadisticas/normalizacion/CIE10/CIE10ES_2018_norm_MANUAL_CODIF_DIAG_. pdf

11. Sonis, S.T. Oral Mucositis, $1^{\text {st }}$ ed.; Springer Healthcare: Tarporley, England, 2012; pp.1-13. https://doi.org/10.1007/978-1-907673-46-7

12. López, F.; Oñate, R.E.; Roldán, R.; \& Cabrerizo, M. C. Measurement of secondary mucositis to oncohematologic treatment by means of different scale. Oral Patol Oral Cir Bucal2005, 10,412- 421. http://scielo.isciii.es/pdf/medicor/v10n5/06.pdf

13. Common Terminology Criteria for Adverse Events (CTCAE) Version 5.0. Available online: https://ctep.cancer.gov/protocolDevelopment/electronic applications/docs/CTC AE v5 Quick Reference 5x7.pdf (27 of November 2017).

14. World Health Organization. Who handbook for reporting results of cancer treatment; WHO: Geneva, Switzerland, $1979 ;$;p. 17. https://apps.who.int/iris/handle/10665/37200

15. Peterson, D. E.; Bensadoun, R.-J.; \&Roila, F. Management of oral and gastrointestinal mucositis: ESMO Clinical Practice Guidelines. Ann Oncol2011,22, vi78-vi84. DOI: 10.1093/annonc/mdr391

16. Elad, S.; Cheng, K.K.F.; Lalla, R.V.; Yarom, N.; Hong, C.; Logan, R.M.; Bowen, J.; Gibson, R.; Saunders, D.P.; Zadik, Y.; Ariyawardana, A.; Correa, M.E.; Ranna, V.; Bossi, P.; \& Mucositis Guidelines Leadership Group of the Multinational Association of Supportive Care in Cancer and International Society of Oral Oncology (MASCC/ISOO).MASCC/ISOO clinical practice guidelines for the management of mucositis secondary to cancer therapy. Cancer 2020, 126, $4423-4431$. DOI: $10.1002 / \mathrm{cncr} .33100$

17. Huang, C-J.; Huang, M-Y.; Fang,P-T.; Chen,F.; Wang,Y-T.; Chen, C-H.; Yuan, S-S.; Huang, C-M.; Luo, K-H.; Chuang, H-Y; Wang, Y-Y.; \& Lee, H-H. Randomized double-blind, placebo-controlled trial evaluating oral glutamine on radiation-induced oral mucositis and dermatitis in head and neck cancer patients. Am J Clin Nutr2019, 109,606-614. DOI: 10.1093/ajcn/nqy329

18. Tsujimoto,T.; Yamamoto,Y.; Wasa,M.; Takenaka,Y.; Nakahara,S.; Takagi,T.; Tsugane, M.; Hayashi, N.; Maeda, K.; Inohara,H.; Uejima, E.; \& Ito,T. L-glutamine decreases the severity of mucositis induced by chemoradiotherapy in patients with locally advanced head and neck cancer: a double-blind, randomized, placebo-controlled trial. Oncol Rep2015, 33,33-39. DOI: $\underline{10.3892 / o r .2014 .3564}$

19. Tanaka,Y.; Takahashi,T.; Yamaguchi, K.; Osada, S.; Shimokawa, T.; \& Yoshida, K. Elemental diet plus glutamine for the prevention of mucositis in esophageal cancer patients receiving chemotherapy: a feasibility study. Support Care Cancer2016, 24, 933-941. DOI: $\underline{10.1007 / \mathrm{s} 00520-015-2864-9}$

20. Pachón, J.; Pereira, J. L.; Osorio G. F.; Irles, J. A.;Serrano, P.;Quintana, B.; Fuentes, J.; Chaves, M.;Ortiz, M. J.; \& García, P. P. Prevention of oral mucositis secondary to antineoplastic treatments in head and neck cancer by supplementation with oral glutamine. Nutr Hosp2018, 35, 428-433. DOI: 10.20960/nh.1467

21. Chang, S-C..;Lai, Y-C.; Hung, J-C.;\& Chang, C-Y. Oral glutamine supplements reduce concurrent chemoradiotherapy-induced esophagitis in patients with advanced non-small cell lung cancer. Medicine2019, 98, 1-4. DOI: 10.1097/MD.0000000000014463

22. Anturlikar, S.D.; Azeemuddin, M.M.; Varma, S.;Mallappa, O.; Niranjan, D.; Krishnaiah, A.B.; Hegde, S.M.; Rafiq, M.; \& Paramesh, R. Turmeric based oral rinse "HTOR-091516" ameliorates experimental oral mucositis. AYU2019, 40, $127-133$. DOI: $10.4103 / a y u . A Y U \_282 \_18$

23. Cho, YK.; Hong, SY.; Jeon, SJ.; Namgung, HW., Lee, E.; Lee, E.; \& Bang, S-M. Efficacy of parenteral glutamine supplementation in adult hematopoietic stem cell transplantation patients. Blood Res2019, 54, 23-30. DOI: 10.5045/br.2019.54.1.23

24. Shumsky, A.; Bilan, E.; Sanz, E.; \& Petrovskiy, F. Oncoxin nutritional supplement in the management of chemotherapy- and/or radiotherapy-associated oral mucositis. Mol Clin Oncol2019, 10, 463-468. DOI: $\underline{10.3892 / m c o .2019 .1809}$ 
25. Widjaja, N. A.;Pratama, A.;Prihaningtyas, R.;Irawan, R.;\& Ugrasena, I. Efficacy Oral Glutamine to Prevent Oral Mucositis and Reduce Hospital Costs During Chemotherapy in Children with Acute Lymphoblastic Leukemia. Asian Pac J Cancer Prev2020, 21, 2117-2121. DOI: 10.31557/APJCP.2020.21.7.2117

26. Harada, K.; Ferdous, T.; Kobayashi, H.; \& Ueyama, Y. Elemental Diet Accelerates the Recovery From Oral Mucositis and Dermatitis Induced by 5-Fluorouracil Through the Induction of Fibroblast Growth Factor 2. Integr Cancer Ther2018, 17, 423-430. DOI: $10.1177 / 1534735417721014$

27. Oosterom, N.; Dirks, N.F.; Heil, S.G.; de Jonge, R.; Tissing, W.J.E.; Pieters, R.; van den Heuvel-Eibrink, M.M.; Heijboer, A.C; \& Pluijm, S.M.F. A decrease in vitamin D levels is associated with methotrexate-induced oral mucositis in 66 children with acute lymphoblastic leukemia. Support Care Cancer2019, 27, 183-190. https://doi.org/10.1007/s00520-018-4312-0

28. Sun, H.; Zhu, X.; Li, D.; \& Cheng, T. Effects of a compound vitamin B mixture in combination with GeneTime® on radiation-induced oral mucositis. J Int Med Res2019, 47, 2127-2134. https://doi.org/10.1177/0300060519831171

29. Nejatinamini, S.; Debenham, B.J.; Clugston, R.D.; Mawani, A.; Parliament, M.; Wismer, W.V.; \& Mazurak, V.C. Poor Vitamin Status is Associated with Skeletal Muscle Loss and Mucositis in Head and Neck Cancer Patients. Nutrients2018, $10,1-11$. DOI: $\underline{10.3390 / \text { nu10091236 }}$

30. Tanaka, Y.; Ueno, T.; Yoshida, N.; Akutsu, Y.; Takeuchi, H.; Baba, H.; Matsubara, H.; Kitagawa, Y.; \& Yoshida, K. The effect of an elemental diet on oral mucositis of esophageal cancer patients treated with DCF chemotherapy: a multi-center prospective feasibility study (EPOC study). Esophagus2018, 15, 239- 248. https://doi.org/10.1007/s10388-018-0620-1

31. Pathak, S.; Soni, T.P.; Sharma, L.M.; Patni, N.; \& Gupta, A. K. A Randomized Controlled Trial to Evaluate the Role and Efficacy of Oral Glutamine in the Treatment of Chemo-radiotherapy-induced Oral Mucositis and Dysphagia in Patients with Oropharynx and Larynx Carcinoma. Cureus2019,11,1-11. DOI: $10.7759 /$ cureus.4855

32. Mamgain, R.K.; Gupta, M.; Mamgain, P.; Verma, S.K.; Pruthi, D.S.; Kandwal, A.; \& Saini, S. The efficacy of an ayurvedic preparation of yashtimadhu (Glycyrrhiza glabra) on radiation-induced mucositis in head-and-neck cancer patients: A pilot study. J Cancer Res Ther2020, 16, 458-462. DOI: 10.4103/jcrt.JCRT_831_16

33. Harada, K.; Minami, H.; Ferdous, T.; Kato, Y.; Umeda, H.; Horinaga, D.; Uchida, K.; Park, S.C.; Hanazawa, H.; Takahashi, S.; Ohota, M.; Matsumoto, H.; Maruta, J.; Kakutani, H.; Aritomi, S.; Shibuya, K.; \& Mishima, K. The Elental ® elemental diet for chemoradiotherapy-induced oral mucositis: A 63 prospective study in patients with oral squamous cell carcinoma. Mol Clin Oncol2019, 10, 159-167. DOI: 10.3892/mco.2018.1769

34. Rao, S.; Hegde, S.K.; Rao, P.; Dinkar, C.; Thilakchand, K.R.; George, T.; Baliga-Rao, M.P.; Palatty, P.L.; \& Baliga, M.S. Honey Mitigates Radiation-Induced Oral Mucositis in Head and Neck Cancer Patients without Affecting the Tumor Response. Foods2017, 6, 1-8. DOI: $10.3390 /$ foods6090077

35. Branda, R.F.; Naud, S.J.; Brooks, E.M.; Chen, Z.; \& Muss, H. Effect of Vitamin B12, Folate, and Dietary Supplements on Breast Carcinoma Chemotherapy-Induced Mucositis and Neutropenia. Cancer2004, 101, 1058-1064. https://doi.org/10.1002/cncr.20484

36. Okada, T.; Nakajima, Y.; Nishikage, T.; Ryotokuji, T.; Miyawaki, Y.; Hoshino, A.; Tokairin, Y.; Kawada, K.; Nagai, K.; \& Kawano, T. A prospective study of nutritional supplementation for preventing oral mucositis in cancer patients receiving chemotherapy. Asia Pac J Clin Nutr2017, 26, 42-48. DOI: 10.6133/apjen.112015.03

37. De Sousa, O.M.; Fontana, N.N.; Seixas, M.T., \& Monteiro, E.M. Effects of Glycine on Collagen, PDGF, and EGF Expression in Model of Oral Mucositis. Nutrients2018, 10, 1-11. DOI: 10.3390/nu10101485

38. Nihei, S.; Sato, J.; Komatsu, H.; Ishida, K.; Kimura, T.; Tomita, T.; \& Kudo, K. The efficacy of sodium azulene sulfonate L-glutamine for managing chemotherapy-induced oral mucositis in cancer patients: a prospective comparative study. J Pharm Health Care Sci2018, 4, 1-6. DOI: 10.1186/s40780-018-0114-2

39. Chattopadhyay, S.; Saha, A.; Azam, M.; Mukherjee, A.; \& Sur, P.K. Role of oral glutamine in alleviation and prevention of radiation-induced oral mucositis: A prospective randomized study. South Asian J Cancer2014, 3, 8-12. DOI: $10.4103 / 2278-330 X .126501$

40. Üçüncü, H.; Ertekin, M.V.; Yörük, Ö.; Sezen, O.; Özkan, A.;Erdoğan, F.; Kızıltunç, A.; \& Gündoğdu, C. Vitamin E and L-carnitine, Separately or in Combination, in The Prevention of Radiation-induced Oral Mucositis and Myelosuppression: a Controlled Study in A Rat Model. J Radiat Res2006, 47, 91-102. DOI: 10.1269/jrr.47.91

41. Amanat, A.; Ahmed, A.; Kazmi, A.; \& Aziz, B. The Effect of Honey on Radiation-induced Oral Mucositis in Head and Neck Cancer Patients. Indian J Palliat Care2017, 23, 317-320. DOI: 10.4103/IIPC.I]PC 14616

42. Podlesko, A.M.; Ramacciati, N.; Serenella, P.; Simonetta, S.; Fiorucci, S.; Pierini, D.; Mancini, M.; Merolla, M.S.; Lancellotta, V.; \& Cynthia, A. Effects of topical polydeoxyribonucleotide on radiation-induced oral mucositis. Tech Innov Patient Support Radiat Oncol2018, 7, 17-19. DOI: 10.1016/j.tipsro.2018.05.003

43. Perrone, A.C.A.S.J.; Rodrigues, T.; da Silva, F.L.; Perrone, I.T.; de Carvalho, A.F.; Stephani, R.; dos Santos, K.B.; Atalla, A.; \& Neto, A.E.H. Supplementation with concentrated milk protein in patients undergoing hematopoietic stem cell transplantation. Nutrition 2017, 37, 1-6. DOI: $10.1016 /$ j.nut.2016.10.010

44. Ogata, Y.; Ishibashi, N.; Yamaguchi, K.; Uchida, S.; Kamei, H.; Nakayama, G.; Hirakawa, H.; Tanigawa, M.; \& Akagi, Y. Preventive effects of amino-acid-rich elemental diet Elental ${ }^{\circledR}$ on chemotherapy-induced oral mucositis in patients with colorectal cancer: a prospective pilot study. Support Care Cancer2016, 24, 783-786. DOI: $\underline{10.1007 / \mathrm{s} 00520-015-2844-0}$

45. Al Jaouni, S.K.; Al Muhayawi, M.S.; Hussein, A.; Elfiki, I.; Al-Raddadi, R.; Al Muhayawi, S.M.; Almasaudi, S.; Kamal, M.A.; \& Harakeh, S. Effects of Honey on Oral Mucositis among Pediatric Cancer Patients Undergoing Chemo/Radiotherapy Treatment 
at King Abdulaziz University Hospital in Jeddah, Kingdom of Saudi Arabia. Evid Based Complement Alternat Med2017, $2017,1-7$. DOI: $\underline{10.1155 / 2017 / 5861024}$

46. Lopez-Vaquero, D.; Gutierrez-Bayard, L.; Rodriguez-Ruiz, J.; Saldaña-Valderas, M.; \& Infante-Cossio, P. Double-blind randomized study of oral glutamine on the management of radio/chemotherapy-induced mucositis and dermatitis in head and neck cáncer. Mol Clin Oncol2017, 6, 931-936. DOI: 10.3892/mco.2017.1238

47. Howlader, D.; Singh, V.; Mohammad, S.; Gupta, S.; Pal, U.S.; \& Pal, M. Effect of Topical Application of Pure Honey in Chemo-radiation-Induced Mucositis and Its Clinical Benefits in Improving Quality of Life in Patients of Oral Squamous Cell Carcinoma. J Maxillofac Oral Surg2019, 18, 73-79. DOI: 10.1007/s12663-017-1077-9

48. Elsass, F.T. A Sweet Solution: The Use of Medical-grade Honey on Oral Mucositis in the Pediatric Oncology Patient. Wounds2017, 29,

115-117. https://www.hmpgloballearningnetwork.com/site/wounds/rapid-communication/sweet-solution-use-medical-grade-honey-or al-mucositis-pediatric

49. Elkerm, Y.; \& Tawashi, R. Date palm pollen as a preventative intervention in radiation- and chemotherapy-induced oral mucositis: a pilot study. Integr Cancer Ther2014, 13, 468-472. DOI: $\underline{10.1177 / 1534735414547110}$

50. Raeessi, M.A.; Raeessi, N.; Panahi, Y.; Gharaie, H; Masoud, S.; Saadat, A.; Karimi, A.A.; Raeessi, F.; Ahmadi, S.M.; \& Jalalian, H. "Coffee plus honey" versus "topical steroid" in the treatment of chemotherapy-induced oral mucositis: a randomised controlled trial. BMC Complement Altern Med2014, 14, 1-7. DOI: 10.1186/1472-6882-14-293

51. Baydar, M.; Dikilitas, M.; Sevinc, A.; \& Aydogdu, I. Prevention of Oral Mucositis Due to 5-Fluorouracil Treatment with Oral Cryotherapy. Prevention of oral mucositis due to 5-fluorouracil treatment with oral cryotherapy. J Natl Med Assoc2005, 97, 1161-1164. https://pubmed.ncbi.nlm.nih.gov/16173332/

52. Peterson, D.E.; Jones, J.B.; \& Petit, R.G. Randomized, placebo-controlled trial of Saforis for prevention and treatment of oral mucositis in breast cancer patients receiving anthracycline-based chemotherapy. Cancer2007, 109, $322-331$. DOI: $\underline{10.1002 / \mathrm{cncr} .22384}$

53. Fogh, S.E.; Deshmukh, S.; Berk, L.B.; Dueck, A.C.; Roof, K.; Yacoub, S.; Gergel, T.; Stephans, K.; Rimner, A.; DeNittis, A.; Pablo, J.; Rineer, J.; Williams, T.M.; \& Bruner, D. A Randomized Phase 2 Trial of Prophylactic Manuka Honey for the Reduction of Chemoradiation Therapy-Induced Esophagitis During the Treatment of Lung Cancer: Results of NRG Oncology RTOG 1012. Int J Radiat Oncol Biol Phys2017, 97, 786-796. DOI: 10.1016/j.ijrobp.2016.11.022

54. Samdariya, S.; Lewis, S.; Kauser, H.; Ahmed, I.; \& Kumar, D. A randomized controlled trial evaluating the role of honey in reducing pain due to radiation induced mucositis in head and neck cancer patients. Indian J Palliat Care2015, 21, 268-273. DOI: $10.4103 / 0973-1075.164892$

55. Matsuda, C.; Munemoto, Y.; Mishima, H.; Nagata, N.; Oshiro, M.; Kataoka, M.; Sakamoto, J.; Aoyama, T.; Morita, S.; \& Kono, T. Double-blind, placebocontrolled, randomized phase II study of TJ-14 (Hangeshashinto) for infusional fluorinated-pyrimidine-based colorectal cancer chemotherapy-induced oral mucositis. Cancer Chemother Pharmacol2015, 76, 97-103. DOI: $\underline{10.1007 / \mathrm{s} 00280-015-2767-\mathrm{y}}$

56. Bateman, E.; Bowen, J.; Stringer, A.; Mayo, B.; Plews, E.; Wignall, A.; Greenberg, N.; Schiffrin, E.; \& Keefe, D. Investigation of Effect of Nutritional Drink on Chemotherapy-Induced Mucosal Injury and Tumor Growth in an Established Animal Model. Nutrients2013, 5, 3948-3963. DOI: 10.3390/nu5103948

57. Jayachandran, S.; \& Balaji, N. Evaluating the effectiveness of topical application of natural honey and benzydamine hydrochloride in the management of radiation mucositis. Indian J Palliat Care2012, 18, 190-195. DOI: 10.4103/0973-1075.105689

58. Sugita, J.; Matsushita, T.; Kashiwazaki, H.; Kosugi, M.; Takahashi, S.; Wakasa, K.; Shiratori, S.; Ibata, M.; Shono, Y.; Shigematsu, A.; Obara, M.; Fujimoto, K.; Endo, T.; Nishio, M.; Kondo, T.; Hashino, S.; Tanaka, J.; Asaka, M.; \& Imamura, M. Efficacy of folinic acid in preventing oral mucositis in allogeneic hematopoietic stem cell transplant patients receiving MTX as prophylaxis for GVHD. Bone Marrow Transplant2012, 47, 258-264. DOI: 10.1038/bmt.2011.53

59. Sorensen, J.B.; Skovsgaard, T.; Bork, E.; Damstrup, L.; \& Ingeberg, S. Double-blind, placebo-controlled, randomized study of chlorhexidine prophylaxis for 5-fluorouracil-based chemotherapy-induced oral mucositis with nonblinded randomized comparison to oral cooling (cryotherapy) in gastrointestinal malignancies. Cancer2008, 112, 1600-1606. DOI: 10.1002/cncr.23328

60. Das, D.; Agarwal, S. K.; \& Chandola, H. M. Protective effect of Yashtimadhu (Glycyrrhiza glabra) against side effects of radiation/chemotherapy in head and neck malignancies. AYU2011, 32, 196-199. DOI: $10.4103 / 0974-8520.92579$

61. Thornley, I.; Lehman, L.E.; Sung, L.; Holmes, C.; Spear, J.M.; Brennan, L.; Vangel, M.; Bechard, L.J.; Richardson, P.; Duggan, C.;\& Guinan, E.C. A multiagent strategy to decrease regimen-related toxicity in children undergoing allogeneic hematopoietic

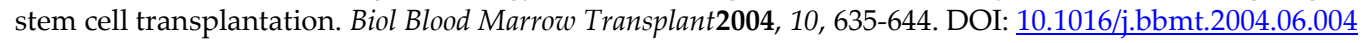

62. Iyama, S.; Sato, T.; Tatsumi, H.; Hashimoto, A.; Tatekoshi, A.; Kamihara, Y.; Horiguchi, H.; Ibata, S.; Ono, K.; Murase, K.; Takada, K.; Sato, Y.; Hayashi, T.; Miyanishi, K.; Akizuki, E.; Nobuoka, T.; Mizugichi, T.; Takimoto, R.; Kobune, M., (...)\& Kato, J. Efficacy of Enteral Supplementation Enriched with Glutamine, Fiber, and Oligosaccharide on Mucosal Injury following Hematopoietic Stem Cell Transplantation. Case Rep Oncol2014, 7, 692-699. DOI: 10.1159/000368714

63. Takano, H.; Momota, Y.; Kani, K.; Aota, K.; Yamamura, Y.; Yamanoi, T.; \& Azuma, M. -tocotrienol prevents 5-FU-induced reactive oxygen species production $\gamma$ in human oral keratinocytes through the stabilization of 5-FU-induced activation of Nrf2. Int J Oncol2015, 46, 1453-1460. DOI: 10.3892/ijo.2015.2849

386 
64. Agha-Hosseini, F.; Pourpasha, M.; Amanlou, M.; \& Moosavi, M-S. Mouthwash Containing Vitamin E, Triamcinolon, and Hyaluronic Acid Compared to Triamcinolone Mouthwash Alone in Patients With Radiotherapy-Induced Oral Mucositis: Randomized Clinical Trial. Front Oncol2021, 11, 1-7. DOI: 10.3389/fonc.2021.614877

65. Yeshurun, M.; Rozovski, U.; Pasvolsky, O.; Wolach, O.; Ram, R.; Amit, O.; Zuckerman, T.; Pek, A.; Rubinstein, M.; Sela-Navon, M.; Raanani, P.; \& Shargian-Alon, L. Efficacy of folinic acid rescue following MTX GVHD prophylaxis: results of a double-blind, randomized, controlled study. Blood Adv2020, 4, 3822-3828. DOI: $\underline{10.1182 / \text { bloodadvances.2020002039 }}$

66. Pattanakitsakul, P.; Chongviriyaphan, N., Pakakasama, S.; \& Apiwattanakul, N. Efect of vitamin A on intestinal mucosal injury in pediatric patients receiving hematopoietic stem cell transplantation and chemotherapy: a quasai-randomized trial. BMC Res Notes2020, 13, 1-6. DOI: 10.1186/s13104-020-05307-8

67. Sung, L.; Robinson, P., Treister, N. ; Baggott, T.; Gibson, P.; Tissing, W.; Wiernikowski, J.; Brinklow, J.; \& Dupuis LL. Guideline for the prevention of oral and oropharyngeal mucositis in children receiving treatment for cancer or undergoing haematopoietic stem cell transplantation. BMJ Support Palliat Care2015, 7, 7-16. DOI: 10.1136/bmjspcare-2014-000804

68. Friend, A.; Rubagumya, F.; \& Cartledge, P. Global Health Journal Club: Is Honey Effective as a Treatment for Chemotherapy-induced Mucositis in Paediatric Oncology Patients?. J Trop Pediatr2018, 64, 162-168. DOI: 10.1093/tropej/fmx092

69. Anderson, PM.; \& Lalla, RV. Glutamine for Amelioration of Radiation and Chemotherapy Associated Mucositis during Cancer Therapy. Nutrients2020, 12, 1-15. DOI: $\underline{10.3390 / \text { nu12061675 }}$

70. Shuai, T.; Tian, X.; Xu, L.; Chen, W.; Pi, Y.; Zhang, L.; Wan, Q.; \& Li, X. Oral Glutamine May Have No Clinical Benefits to Prevent Radiation-Induced Oral Mucositis in Adult Patients With Head and Neck Cancer: A Meta-Analysis of Randomized Controlled Trials. Front Nutr2020, 7, 1-10. DOI: $10.3389 /$ fnut.2020.00049

71. Münstedt, K.; \& Männle, H. Using Bee Products for the Prevention and Treatment of Oral Mucositis Induced by Cancer Treatment. Molecules2019, 24, 1-13. DOI: 10.3390/molecules24173023

72. Tian, X.; Xu, L.; Liu, X.; Chunfeng, C.; Xie, W.; Jiménez-Herrera, M.F.; \& Chen, W. Impact of honey on radiotherapy-induced oral mucositis in patients with head and neck cancer: a systematic review and meta-analysis. Ann Palliat Med2020, 9, $1431-1442$. DOI: $10.21037 / \mathrm{apm}-20-44$

73. Yarom, N.; Hovan, A.; Bossi, P.; Ariyawardana, A.; Jensen, S.B.; Gobbo, M.; Saca-Hazboun, H.; Kandwal, A.; Majorana, A.; Ottaviani, G.; Pentenero, M.; Nasr, N.M.; Rouleau, T.; Skripnik, A.; Treister, N.S.; Zur, E.; Ranna, V.; Vaddi, A.; Fong, K.K., (...); \& Elad, S.; Mucositis Study Group of the Multinational Association of Supportive Care in Cancer / International Society of Oral Oncology (MASCC/ISOO). Systematic review of natural and miscellaneous agents for the management of oral mucositis in cancer patients and clinical practice guidelines-part 1: vitamins, minerals, and nutritional supplements. Support Care Cancer2019, 27, 3997-4010. DOI: $\underline{10.1007 / s 00520-019-04887-x}$

74. Richard, S.A. Exploring the Pivotal Immunomodulatory and Anti-Inflammatory Potentials of Glycyrrhizic and Glycyrrhetinic Acids. Mediators Inflamm2021, 2021, 1-15. DOI: $10.1155 / 2021 / 6699560$

75. López-González, A.; García-Quintanilla, M.; Guerrero-Agenjo, C.M.; López, J.; Guisado-Requena, I.M.; \& Rabanales-Sotos, J. Eficacy of Cryotherapy in the Prevention of Oral Mucosistis in Adult Patients with Chemotherapy. Int J Environ Res Public Health2021, 18, 1-15. DOI: $10.3390 /$ ijerph18030994 